Illinois State University

ISU ReD: Research and eData

Theses and Dissertations

3-17-2016

\title{
The Role of the Institution on the Adoption of Law Enforcement Technology
}

Cassandra Dodge

Illinois State University, cedodge@ilstu.edu

Follow this and additional works at: https://ir.library.illinoisstate.edu/etd

Part of the Criminology Commons, and the Criminology and Criminal Justice Commons

\section{Recommended Citation}

Dodge, Cassandra, "The Role of the Institution on the Adoption of Law Enforcement Technology" (2016). Theses and Dissertations. 495.

https://ir.library.illinoisstate.edu/etd/495

This Thesis is brought to you for free and open access by ISU ReD: Research and eData. It has been accepted for inclusion in Theses and Dissertations by an authorized administrator of ISU ReD: Research and eData. For more information, please contact ISUReD@ilstu.edu. 


\title{
THE ROLE OF THE INSTITUTION ON THE ADOPTION OF LAW ENFORCEMENT TECHNOLOGY
}

\author{
Cassandra E. Dodge
}

\section{Pages}

While law enforcement agencies perceive that technology increases their ability to complete their mission in the most efficient manner possible, this may not be the case in reality. Considering the potential expenses, potential danger, and lack of proven efficiency, it is surprising that these technologies are continuing to be adopted. Observing law enforcement agencies through the lens of institutional theory provides an explanation for the discrepancy between what would be expected and what has actually occurred. The purpose of this exploratory study was to examine the use of five technologies (records management systems, broadband networking with vehicle computers, long range acoustic devices, patrol vehicle cameras, and body-worn cameras) by county and municipal law enforcement agencies. The data were derived from a survey that was completed by 106 county and municipal law enforcement agencies located in five states within the United States. Statistical analyses were completed to measure the influences of organizational complexity, jurisdictional complexity, funding, and organizational myths on the decision to adopt these technologies. While no significant relationship was indicated between 
institutional factors and technology adoption overall, analysis of the individual technologies did indicate relationships in some cases. The organizational myths of officer safety, efficiency, and community safety were consistently cited as influences for the adoption of technology.

KEYWORDS: Law Enforcement, Technology, Institutional Theory 
THE ROLE OF THE INSTITUTION ON THE ADOPTION OF LAW ENFORCEMENT TECHNOLOGY

CASSANDRA E. DODGE

A Thesis Submitted in Partial

Fulfillment of the Requirements for the Degree of

MASTER OF SCIENCE

Department of Criminal Justice Sciences

ILLINOIS STATE UNIVERSITY

2016 
(C) 2016 Cassandra E. Dodge 
THE ROLE OF THE INSTITUTION ON THE ADOPTION OF LAW ENFORCEMENT TECHNOLOGY

CASSANDRA E. DODGE

COMMITTEE MEMBERS:

Cara Rabe-Hemp, Chair

Jason Ingram

Michael Rossler 


\section{ACKNOWLEDGMENTS}

It would be remiss of me to not acknowledge those individuals without whom this thesis would have never been possible. Dr. Cara Rabe-Hemp, the catalyst for this project, has been my guide and support during one of the hardest years of my life. I owe you so much. Dr. Jason Ingram and Dr. Michael Rossler, thank you for agreeing to be a part of my thesis committee. Your insight into policing and statistical analysis was fundamental to the success of this research. Dr. Ralph Weisheit's expertise and feedback was instrumental in the development and formatting of the survey distributed for this research. The logistical assistance provided by Jenny Doutt made this process of survey distribution much less painful. The surveys were developed and distributed in conjunction with Cayla Comens. I could not have taken on such a task without one of my closest friends. While they were not directly a part of this research, I also want to acknowledge three women have been integral to my success in this program: Dr. Jacqueline Schneider, Dr. Sesha Kethineni, and Dr. Shelly Clevenger. Each of you encouraged me and tested me throughout my studies. I feel I rose to the challenge, and I hope to do the Department of Criminal Justice Sciences proud. To my family and the graduate cohort: thank you for your unwavering support. 
Finally, I would like to dedicate this document to the memory of my father, David Dodge. A law enforcement officer of 25 years, he spent countless hours discussing this research with me. I miss you, but I know you would be proud of what was accomplished here. I love you, Dad.

C. E. D. 


\section{CONTENTS}

\section{Page}

ACKNOWLEDGMENTS

CONTENTS

TABLES

FIGURES

viii

\section{CHAPTER}

I. INTRODUCTION 1

Introduction 1

Theoretical Framework $\quad 3$

Study Objectives 4

Contributions to the Field $\quad 5$

Thesis Overview $\quad 5$

$\begin{array}{ll}\text { II. } & \text { LITERATURE REVIEW }\end{array}$

$\begin{array}{lr}\text { Introduction } & 7\end{array}$

$\begin{array}{ll}\text { Technological Equipment } & 10\end{array}$

Computer-Based Records Management System 10

Efficiency, effectiveness, and other concerns $\quad 11$

Broadband Networking with Vehicle Computer Systems 12

Efficiency, effectiveness, and other concerns 13

Long Range Acoustic Device 15

Efficiency, effectiveness, and other concerns 16

$\begin{array}{ll}\text { Patrol Vehicle Cameras } & 17\end{array}$ 
$\begin{array}{ll}\text { Body-Worn Cameras } & 20\end{array}$

Efficiency, effectiveness, and other concerns $\quad 21$

$\begin{array}{ll}\text { Conclusion } & 25\end{array}$

III. THEORETICAL FRAMEWORK 27

$\begin{array}{ll}\text { Introduction } & 27\end{array}$

Institutional Theory 28

Application to Law Enforcement Organizations 31

Theoretical Research $\quad 32$

Empirical Research 34

Application to Current Study $\quad 36$

$\begin{array}{ll}\text { IV. METHODOLOGY } & 40\end{array}$

$\begin{array}{ll}\text { Introduction } & 40\end{array}$

Setting $\quad 43$

Sample Selection Criteria $\quad 43$

Data Collection $\quad 45$

Variables $\quad 46$

Dependent Variables $\quad 46$

Independent Variables $\quad 47$

$\begin{array}{ll}\text { Data Analysis } & 49\end{array}$

V. RESULTS 51

Introduction $\quad 51$

Univariate Analysis $\quad 52$

Bivariate Analysis $\quad 56$

Multivariate Analysis 64

Conclusion $\quad 68$

$\begin{array}{lll}\text { VI. DISCUSSION } & 70\end{array}$

$\begin{array}{ll}\text { Introduction } & 70\end{array}$

$\begin{array}{ll}\text { Discussion } & 71\end{array}$ 
$\begin{array}{ll}\text { Organizational Complexity } & 71\end{array}$

Jurisdictional Complexity $\quad 72$

$\begin{array}{ll}\text { Funding } & 73\end{array}$

Justifications for Technology Adoption $\quad 75$

$\begin{array}{ll}\text { Other Findings } & 75\end{array}$

$\begin{array}{ll}\text { Limitations } & 76\end{array}$

Recommendations for Future Research $\quad 78$

$\begin{array}{ll}\text { Conclusion } & 79\end{array}$

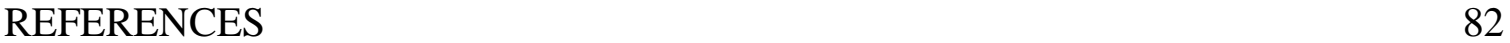

APPENDIX A: Survey Distributed to Agencies $\quad 88$ 


\section{TABLES}

Table

Page

1. Descriptive Statistics 53

2. Justification Frequencies 55

3. Relationship Between Organizational Complexity Factors and RMS Adoption

4. Relationship Between Organizational Complexity Factors and Broadband Adoption $\quad 58$

5. Relationship Between Organizational Complexity Factors and Patrol Camera Adoption

6. Relationship Between Organizational Complexity Factors and BWC Adoption

7. Relationship Between Jurisdictional Complexity and Adoption of RMS

8. Relationship Between Jurisdictional Complexity and Adoption of Broadband Networking

9. Relationship Between Jurisdictional Complexity and Adoption of Patrol Vehicle Cameras

10. Relationship Between Jurisdictional Complexity and Adoption of BWC

11. Relationship Between Internal Funding and Adoption of RMS

12. Relationship Between Internal Funding and Adoption of Broadband Networking 
13. Relationship Between Internal Funding and Adoption of Patrol Vehicle Cameras

14. Relationship Between Internal Funding and Adoption of BWC

15. Relationship Between External Funding and Adoption of RMS

16. Relationship Between External Funding and Adoption of Broadband Networking

17. Relationship Between External Funding and Adoption of Patrol Vehicle Cameras

18. Relationship Between External Funding and Adoption of BWC

19. Bivariate Correlation Matrix 64

20. Multicollinearity Diagnostics 65

21. OLS Regression for Prediction of Technology Adoption 68 


\section{FIGURES}

Figure

Page

1. THMI Diagnostic

66

2. Normal P-P Plot 


\section{CHAPTER I \\ INTRODUCTION}

\section{Introduction}

Technology's role in law enforcement historically has had a substantial effect on how law enforcement officers complete their duties. Early technologies, such as the patrol vehicle, telephones, and two-way radios, were integral in the development of the modern law enforcement agency. The inclusion of evolving technology has developed and expanded the mission of law enforcement from solving crimes and answering calls for service to crime prevention (Dunham \& Albert, 2015; Wexler, 2012). Some technologies have acted as force multipliers, allowing agencies to maintain legitimacy during periods of financial crisis (Wexler, 2012). For example, the use of mobile computer terminals resulted in time savings equivalent to 10 percent of the patrol strength for one law enforcement agency (Agrawal, Rao, \& Sanders, 2003). Budget concerns may mean an agency cannot hire as many field officers, but some technologies may offer benefits that increase the productivity of the few.

Early iterations of technology may not have been designed with law enforcement applications in mind, but the utility of such technologies are often recognized and are adopted by agencies. The telephone and automobile are early examples of technology that were easily appropriated by law enforcement. More recent technological developments, such as digital recording and computing, have become standard equipment 
for law enforcement. Even Facebook and Twitter have found utility in law enforcement. As much as 83 percent of law enforcement agencies use social media platforms to disseminate information to their communities, with 70 percent using social media platforms as a way to retrieve information (Wexler, 2012). These technologies may fill holes in law enforcement capabilities, but first the hole must be identified. Needs assessments are one way for law enforcement agencies to identify areas for technological improvement. Recent needs assessments have identified communications technologies, patrol vehicle systems, management technology, mobile data, and cameras as some of the areas of concern for many agencies nationally (IACP, 2005; Koper, Taylor, \& Kubu, 2009).

While law enforcement agencies perceive that technology increases their ability to complete their mission in the most efficient manner possible, this may not be the case in reality. Some problems include concerns about the safety of deployed equipment, the limited capabilities of the equipment as they are currently designed, legal restrictions on the use of certain technologies, as well as the monetary expenses of implementation and upkeep. Legitimacy is also of grave concern for law enforcement agencies, especially as recent events have shaken the perception of law enforcement agencies as organizations of fair and equal justice. Fears of militarized police forces have resulted in the review of whether or not certain technologies are appropriate for use by civilian agencies; however, the desire for officer accountability has resulted in an outcry for additional technologies, such as body-worn cameras (The White House Office of the Press Secretary, 2014). Considering the potential expenses, potential danger, and lack of proven efficiency, it is surprising that these technologies are continuing to be adopted. The intent of the current 
inquiry was to explore factors related to the adoption of a variety of law enforcement technologies.

\section{Theoretical Framework}

When conducting research on law enforcement organizations' decision-making processes, the implementations of certain technologies do not necessarily make sense if observed from a normative perspective. As already identified, many emerging technologies are not empirically supported as efficient in addressing various crime problems, nor do they consistently increase the efficiency of line officers during the course of their duties. Some common technologies in question include cell phones, computers with web browsers, and mobile computer terminals with messaging capabilities. Normative perspectives of organizations would expect agencies to discard such technologies, though this did not appear to be the case (Mastrofski \& Uchida, 1996). Observing law enforcement agencies through the lens of institutional theory provided an explanation for the discrepancy between what would be expected and what actually occurred.

Institutional theorists assert that government organizations, such as law enforcement agencies, operate in an institutional environment that includes sovereigns, or stakeholder entities who have the ability to affect the well-being of the organization and whose opinions and values are of upmost importance to the organization in question. This is because the sovereigns are the source of the organization's legitimacy. Sovereigns of law enforcement agencies include the community they serve, the government entities they operate under, and may even include the officers that work for the agency. An 
organization must conform to the values of these sovereigns in order to survive (Scott \& Meyer, 1983; Crank \& Langworthy, 1992).

While institutional theory has been successfully applied to law enforcement agencies when studying various subjects, such as police organizations and practices, leadership style, specialty units, and policing movements, it had not been applied to research exclusively analyzing general decisions effecting the implementation of technology within law enforcement agencies (Crank, 1994; Engel, Calnon, \& Bernard, 2001; Katz, 2001; Ritti \& Mastroski, 2002). The current study looked to expand the application of institutional theory to this aspect of law enforcement, supporting prior research study's assertions that the constraining and enabling effects of an institutional environment are the main source of policy decisions.

\section{Study Objectives}

The purpose of this study was to examine the use of five technologies by county and municipal law enforcement agencies. A survey was developed and distributed to a sample of 902 county and municipal law enforcement agencies located in five states within the United States. Police administrators from these agencies were supplied with the survey in either a digital or physical format between November and December of 2015. The exploratory study looked to answer the following questions: (1) How does the organizational complexity (i.e. number of officers employed, number of bureaus and divisions, and number of ranks) of a law enforcement agency influence the decision to adopt new technologies? (2) How does the jurisdictional complexity (i.e. whether the community is urban, suburban, or rural) of a law enforcement agency influence the decision to adopt new technologies? (3) Does the presence of funding (i.e. internal and 
external) influence the likelihood that an agency will adopt new technology? (4) What are some common justifications for adopting records management systems, broadband networking with vehicle computers, long range acoustic devices, patrol vehicle cameras, and body-worn cameras?

\section{Contributions to the Field}

Prior research on individual technologies has identified that many popular technologies employed by law enforcement do little to increase the efficiency of the organization (Amnesty International, 2014; Carter \& Grommon, 2014; Gordon et al, 2012; NIJ, 2014; Westphal, 2004; White House, 2011). The application of institutional theory potentially provided explanations for the discrepancy between empirical research on technological advances, specifically the limited success of various technologies, and the continued implementation of the technologies. This study expanded upon knowledge in the area of law enforcement technologies by identifying influences on organizational decision-making processes within the framework of institutional theory.

\section{Thesis Overview}

In order to preface the subject of law enforcement technology and current research on the subject, chapter 2 includes a comprehensive literature review covering the general topic of law enforcement technology, as well as coverage of research specific to the technologies that are of concern within this study. The theoretical framework for this study is covered in chapter 3 . The chapter defines institutional theory, and includes examples of the theory's application to law enforcement agencies. It also includes an explanation of how the theory was applied within the current study. Chapter 4 covers the study's methodology, outlining the proposed research design including information about 
the sampling methodology, variables, data collection, and analysis methods. Chapter 5 details the results of the statistical analyses completed. Chapter 6 discusses the findings in the context of prior research, also covering the limitations of this study and the recommendations for future research. 


\section{CHAPTER II}

\section{LITERATURE REVIEW}

\section{Introduction}

Emerging technologies being utilized by law enforcement is not a new concept. From the early to mid-twentieth century, police agencies radically changed how they operated following the introduction of patrol vehicles, telephones, and two-way radios. These developments increased the efficiency of law enforcement, allowing citizens to call for service while officers were able to be dispatched to specific locations rather than have citizens attempting to find officers walking their beats (Dunham \& Alpert, 2015).

The following decades saw further developments in technology used by law enforcement agencies which were a direct reflection of the changing mission of law enforcement agencies from a reactive to proactive mindset (Wexler, 2012). Proactive policing is not the only motivator towards adoption of technology in law enforcement. Following the financial crisis of 2008, many agencies faced budget cuts that resulted in the reduction of agencies' manpower. In some cases, technology offered potential force multiplier effects, counteracting problems with manpower. Unfortunately, technology is often costly, resulting in reductions of technology use unless grants of alternative funding could be identified (Wexler, 2012).

While occasionally new technologies address unrealized issues in law enforcement, agencies typically have a strong idea of what types of technologies could 
potentially address specific needs. Needs assessments are a common methodological tool for identifying these issues. Within the last ten years, the National Institute of Justice, International Association of Chiefs of Police, and the Police Executive Research Forum have each completed needs assessments focused on law enforcement technology. Evaluation of each of these assessments revealed common technological trends between agencies. Some priorities identified include the protection of the public and the officer, increasing officer efficiency, information sharing, collection of digital evidence, and informed decision making (NIJ, 2010; Koper, Taylor, \& Kubu, 2009; IACP, 2005; Gordon et al, 2012). In 2005, law enforcement agencies identified communication technologies, patrol vehicle technologies, management technology, forensics, and video cameras as their top categories of available technology. In particular, they were interested in acquiring mobile data terminals for vehicles, patrol vehicle cameras, satellite-mobile data, and records management systems (IACP, 2005). Four years later, the trends continued with database integration, video surveillance, and wireless access in vehicles remaining top priorities. Patrol vehicle and body-worn cameras were also of interest (Koper, Taylor, \& Kubu, 2009). A survey conducted by the Police Executive Research Forum in 2011 indicated that commonly implemented technology included predictive policing technology, in-car cameras, wireless video streaming, license plate readers, global positioning systems (GPS), and social media (Wexler, 2012). When asked what barriers prevent acquisition and implementation of technology, agencies cited financial constraints, training, leadership, police culture, and politics as obstacles (Koper, Taylor, \& Kubu, 2009). 
This is not to say that the adoption of certain technologies by law enforcement are not controversial. Surveillance technologies, such as closed-circuit television systems and license plate readers, bring up concerns about privacy and Fourth amendment violations. While the courts have generally validated the legality of these technologies, as they are implemented in public spaces where there is no reasonable expectation of privacy, these technologies are continuously challenged (IACP, 2012; NIJ 2003; see also predictive policing, Pearsall, 2010). Similarly, current events, including the high profile police shooting of Mike Brown in Missouri in 2014 and the resulting protests, have led to a crisis in legitimacy for police on a national level. Images of officers in full tactical gear, armed with military grade equipment, depicted law enforcement as an occupying force. These incidents brought the Department of Defense's 1033 program, an equipment program that provided used military equipment to law enforcement agencies at little to no cost, under scrutiny (Else, 2014).

The following study is designed to address five specific types of law enforcement technology, including computer-based records management systems (RMS), broadband networking with vehicle computer systems, long-range acoustic devices, patrol vehicle cameras, and body-worn cameras. These five are of particular interest as each of these technologies fall under the priorities identified by prior needs assessments (NIJ, 2010; Koper, Taylor, \& Kubu, 2009; IACP, 2005; Gordon et al., 2012). Background for each technology, including their utility in law enforcement functions, will be provided. Finally, the efficiency and effectiveness of these technologies will be addressed, along with any other implementation concerns. 


\section{Technological Equipment}

\section{Computer-Based Records Management System}

Computers have become an accepted tool for record keeping within law enforcement agencies over the last 30 years. The use of computers for records management has increased from 14 percent to 76 percent between 1987 and 2003 (Garicano \& Heaton, 2010). A computer-based records management system is any "agency-wide system that provides for the storage, retrieval, retention, manipulation, archiving, and viewing of records, documents, or files pertaining to law enforcement operations" (International Association of Crime Analysts [IACA] Standards, Methods, and Technology Committee, 2013, p. 1). A record is any piece of "information created, received, and maintained as evidence and information by an organization or person, in pursuance of legal obligations or in the transaction of business" (Federal Bureau of Investigation, n.d., p. 4). A RMS is meant to be used for the entirety of the records' development life cycle (Law Enforcement Information Technology Standards Council [LEITSC], 2010). Its primary purpose is to serve as the database for crime-related information, though fully-integrated systems may have multiple capabilities, such as handling calls for service, incident reports, case management, evidence management, warrants, arrests, booking, and more (LEITSC, 2010; IACA, 2013). In 2003, the LEITSC began the process of developing a national standard for RMS functional specifications, aiming to provide a framework for agencies to work with when developing their own systems, reducing system costs, and to promote RMS that are designed with information sharing capabilities (LEITSC, 2010). Such capabilities are of particular importance to the 
FBI, as it supports their anti-terrorism and national crime investigation missions. In the FBI's report on RMS, they reiterated the importance of all data:

Calls for service records and investigative, arrest, criminal identification, detention, and even civil records hold information that by themselves mean little; however, when pieced together with information from other jurisdictions, the result can help with all levels of investigations and aid in safeguarding the Nation (FBI, n.d., p. 2).

Successful records management is also helpful in meeting federal requirements for information submitted for the Uniform Crime Report (UCR) and National Data Exchange (N-DEx), as well as provide for submission of pertinent information to the National Crime Information Center (NCIC) (FBI, n.d.).

Efficiency, effectiveness, and other concerns. Little empirical research has been conducted on RMS; however, an evaluation of Chicago's Citizen and Law Enforcement Analysis and Reporting (CLEAR) system does provide insight into the development of a large scale, shared RMS. The data warehouse was a result of a 35 million dollar software development program, led by Oracle, a major business software designer, and the Chicago Police Department (CPD). The software was developed specifically for use in the public sector, intending to increase the accountability, efficiency, and effectiveness of law enforcement agencies in the Chicago area. Since its development, the CPD has opened access to CLEAR across the state. As a result, the Illinois State Police Department and CPD are in discussion about developing a state-wide records management system (Skogan, Harnett, \& DuBois, 2003).

Several concerns in regards to software development and implementation of a large scale RMS were identified in the evaluation. The software was developed to address the specific needs of the agency. Agencies the size of the CPD exhibit problems with 
communication between agency divisions. If each division requests similar functionality, the system is at risk for programming redundancies and inefficiencies, making the system more difficult to navigate. While it is not addressed in the evaluation of the CLEAR system, the custom design of the system may not be applicable to external entities, discouraging agencies from adopting the system. Another concern identified in the evaluation of CLEAR should be a concern for all RMS. By design, RMS should be accessible to officers at an agency terminal. Administrative safeguards are needed to ensure access to agency records is limited to work-related purposes and prevent abuses of the RMS (Skogan, Harnett, \& DuBois, 2003).

\section{Broadband Networking with Vehicle Computer Systems}

Mobile computing is not a new law enforcement technology. The message status terminal (MST) was introduced in the early 1960s, allowing for communication between dispatch and field officers without using radios. The original units were only able to communicate in one direction, officer to dispatch, though later developments allowed for two-way communication between the officer and dispatch as well as car-to-car with other field officers (Ioimo \& Aronson, 2004). Modern mobile computing terminals (MCT) evolved from MSTs, increasing the overall capabilities of field officers. Fundamentally, the patrol vehicle has become a mobile office where field officers can perform a variety of tasks without stepping foot out of their vehicles. Broadband wireless networks allow for greater access to valuable information previously inaccessible through the use of the terminals, such as video and image data. Broadband systems also allow officers to communicate with other officers and administration through the use of email, reducing 
unnecessary radio traffic. The ready availability of pertinent information has also been connected to increased job satisfaction of field officers (Agrawal, Rao, \& Sanders, 2004).

While broadband wireless systems have started to be included in MCTs, the public safety sector, including law enforcement agencies, still primarily rely on Land Mobile Radio (LMR) devices for communication. During his State of the Union address in 2011, President Obama announced the Wireless Innovation and Infrastructure Initiative. The initiative calls for the development of a nationwide wireless network, dedicated to use by public safety organizations, utilizing current $4 \mathrm{G}$ networking technology. The goal is to enhance the effectiveness of first responders through the use of an interoperable communications and information system. Such a system may also reduce reliance on commercial enterprises that currently provide broadband services to law enforcement agencies, such as cellular providers Sprint and Verizon (The White House, 2011).

Efficiency, effectiveness, and other concerns. Results of empirical studies on the deployment of MCTs are mixed. Early studies indicated that the MCTs increased the efficiency of field officers due to time savings. In a study of a law enforcement agency with 649 officers found that MCTs were able to complete work equivalent to that of 68 officers by assisting in tasks such as license plate checks, execution of summons, and execution of warrants (Agrawal, Rao, \& Sanders, 2003). Alternatively, Ioimo and Aronson (2004) indicate that there is not a significant relationship between the use of MCTs and the productivity of field officers; in fact, they found that the use of MCTs increases the amount of time field officers spend writing reports. However, they also 
indicated that the use of MCTs by field officers incurs significant benefits towards records management, investigation clearance, and administration.

With broadband networking comes several logistical problems. First, rural departments must deal with the existing communications infrastructure in their jurisdictions. Second, device sophistication is worthless if the cell-tower coverage is weak. Sixty-two percent of small departments surveyed in the NIJ study identified technology sophistication and lack of communications infrastructure as problematic for their agencies. Third, infrastructure that does exist may be vulnerable to natural and manmade disasters (Gordon et al, 2012; White House, 2011).

Admittedly, there are other options that assist in dealing with this problem. Instead of relying on commercial infrastructure, some agencies are able to install a broadband network consisting on hundreds of access points within the municipality, so officers are always connected to the strongest wireless signal in their patrol area (Carter \& Grommon, 2014). Even for those departments with stronger infrastructure, the cost to maintain an efficient broadband network system can be problematic. As the number of sworn officers increases, so does the required bandwidth capacity and overall cost of maintaining the broadband system. Large agencies must deal with the increase broadband costs. New York City's Department of Information Technology and Telecommunications awarded the Northrop Grumman Corporation a contract to develop a broadband wireless network dedicated solely to public safety. The five year contract cost $\$ 500$ million dollars (Northrop, 2006). Small, rural agencies may not be able to afford installing alternatives to commercial broadband within their jurisdictions (Gordon et al, 2012; Carter \& Grommon, 2014). 
The use of MCTs and broadband communications present safety concerns for officers. There are concerns regarding the distraction the terminals present to officers on the road. When interviewed about the issue, Chief Darren Harvey, of Greenville, Kentucky, stated, "We have to train officers to pay attention on the road. The distraction of in-car technology is no different than a cell phone" (Darst, 2014, p. 65). At night, these terminals decrease officer's situational awareness, as they lose night vision, and increase their visibility to individuals outside of their vehicles. According to the FBI, ambush attacks on officers account for 23.2 percent of officer deaths between 2002 and 2011.

\section{Long Range Acoustic Device}

The Long-Range Acoustic Device (LRAD) was developed for the military in response to the October $12^{\text {th }}, 2000$, terrorist attack on the U.S.S. Cole. The technology was meant to fill a gap in the security of in-transit military resources (Schrantz, 2010). Primarily designed as a communication device, LRAD addressed several flaws inherent in conventional public address systems. Conventional speakers utilize electromagnets to create sound. These sound waves disperse in all directions, exposing the operator and others outside of the targeted area to sound waves. This can be problematic as this could endanger innocent bystanders and security personnel to potentially harmful sound waves. Additionally, the sound waves created by conventional speakers disperse over larger distances, resulting in poorer sound quality the further from the source the listener stands. Addressing these flaws, LRAD systems use multiple proprietary drivers to create highly focused and directional sound waves, reducing exposure to these sound waves if not in the targeted range of the device, and increasing the clarity of sound at farther distances 
(LRAD, 2014b). LRAD systems are advertised as being 25 to 30 decibels louder than traditional bullhorns (LRAD, 2014a).

The communication capabilities afforded through the use of LRAD have a multitude of scenarios in which it could be employed by law enforcement and other first responders. SWAT teams can implement LRAD as a way to communicate warnings and instructions to citizens in order to secure areas subject to high-risk maneuvers, including warrants and hostage scenarios, all while staying a safe distance away from potentially violent offenders. Some LRAD units have been augmented for emergency notification purposes. Because of its design, LRAD can be heard over aircraft noise, allowing search and rescue helicopter units to use the system.

The final, and most controversial purpose of the LRAD system is as a crowd control device. In addition to projecting voice commands, LRAD has a feature advertised as a deterrent tone. This sound consists of a fast-tempo, high-pitched sound, which is directed at crowds as a method of incapacitation and dispersal. The intensity of this sound increases according to the subjects' proximity to the LRAD unit. Within 20 meters, the subject would potentially be exposed to 120 decibels, which is equal to the human threshold for pain (LRAD, 2014a).

Efficiency, effectiveness, and other concerns. The controversy around LRAD's deterrence tone feature revolves around the argument of whether the device should be classified it as a less than lethal weapon. In an article from The Army Lawyer, by Major Joe Schrantz (2010), the U.S. military's decision to classify of LRAD as a less-than lethal weapon was explained: 
Should the LRAD be employed with the intent to cause discomfort to the listener, it would be considered a non-lethal weapon, but because the discomfort is well short of permanent damage to the ear, it does not violate the legal threshold of 'superfluous injury or unnecessary suffering' (p. 58).

According to LRAD's brochure for law enforcement (2014a), LRAD produces sound waves of 88 decibels from 500 to 1800 feet away from the operating unit. According to the National Institutes of Health (2014), "long or repeated exposure to sounds at or above 85 decibels can cause hearing loss" (p. 1). To put this in context, the area in which a person may be exposed to levels high enough to cause permanent hearing loss is approximately within seven city blocks of an operating LRAD unit (LRAD, 2014a; NIH, 2014). LRAD Corporation justifies the system's utility as a less-than-lethal weapon stating, "just the act of covering ears with hands reduces the sound pressure level (SPL) by approximately $25 \mathrm{~dB}$ (decibels) and could prevent protestors from throwing projectiles" (LRAD, 2014a, p. 2). In addition to the potential for hearing loss, other effects of LRAD exposure include nausea, loss of balance, and eardrum rupture (Amnesty International, 2014). There is a lack of empirical data involving the use of LRAD at this time, including its efficiency as a crowd control device.

\section{Patrol Vehicle Cameras}

The use of patrol vehicle cameras, also known as in-car cameras or "dash-cams," can be traced back to an experiment by the Connecticut State Police in the late 1960s, whose installed recording system proved to be too cumbersome and impractical. As recording technologies improved, the benefits of vehicle-borne recording devices became more apparent, specifically for its role in collecting evidence from traffic stops. Mothers Against Drunk Driving (MADD) helped fund the purchase of these cameras in the 1980s to assist with prosecutions of impaired drivers. These cameras were also instrumental in 
documenting vehicle search consent during drug interdiction stops in the 1990s.

However, it was not until the late 1990s and early 2000s that law enforcement agencies began adopting patrol vehicle cameras in force. Allegations of racial profiling and aggression towards law enforcement officers spurred efforts to help agencies afford patrol vehicle cameras. In 2000, the Office of Community Oriented Policing Services (COPS) initiated the In-Car Camera Initiative Program (International Association of Chiefs of Police, 2004; Nash \& Scarberry, 2014). Patrol vehicle cameras in state police and highway patrol vehicles increased from 11 percent of all vehicles in 2000 to 72 percent of all vehicles by 2004 (IACP, 2004). In 2003, only 55 percent of local police departments had patrol vehicle cameras. This increased to 61 percent by 2007 (Reaves, 2010). In a survey of over 70 agencies, the Police Executive Research Forum indicated that 71 percent of the agencies used patrol vehicle cameras, though only 25 percent of the agencies had them installed in all of their patrol vehicles (Wexler, 2012).

Efficiency, effectiveness, and other concerns. The primary purpose of a patrol vehicle camera has historically been to serve as a source of evidence during traffic stops. When surveyed, 91 percent of prosecutors said they used patrol vehicle camera footage as evidence in criminal court proceedings. They also stated that the availability of video evidence increased their ability to get convictions and plea agreements (IACP, 2004). Sometimes, the collected evidence involves the conduct of the officers as well as the suspect. In a review of patrol vehicle cameras by the International Association of Chiefs of Police (2004), five percent of citizen complaints against officers were sustained through video evidence provided by patrol vehicle camera footage. In a separate study, 3,000 officers were surveyed about patrol vehicle cameras. When asked about citizen 
complaints, 96.2 percent said they had experienced citizen complaints, but were cleared by video evidence. When supervisors were interviewed in the same study, they claimed that complainants withdrew grievances more than half the time after being told the incident was filmed (Westphal, 2004). It has also been used to exonerate officers from wrongdoing in court. The 2011 case involving the fatal police shooting of Seth McCloskey is one example of a patrol vehicle camera's utility for such a case. An eyewitness testified that the officers were lying when they testified that McCloskey had exited his vehicle and fired a weapon at the officers. The video recording corroborated the officers' version of the incident (Nash \& Scarberry, 2014).

Outside of its utility as an evidentiary tool, patrol vehicle recordings have been effective in increasing officer safety and performance. Research interviews revealed that officers would review video to critique their own behavior, identifying dangerous habits, such as turning his or her back to a possibly dangerous subject, and improve upon their approaches in the future. Officers interviewed also indicated that they would tell citizens they were being recorded as a de-escalation method in potentially hazardous situations. In addition to its application to safety training and self-critique, officers used footage in the composition of reports and for court room preparation since the footage was the most accurate representation of the interaction. Regrettably, this has also resulted in a loss of note-taking skills (Westphal, 2004).

Overall, the public appears to approve of the use of patrol vehicle cameras as it keeps officers and the public accountable for their actions. However, many are misinformed as to the capabilities of patrol vehicle cameras and their presence during patrol stops. Citizens interviewed were under the assumption that the camera was not 
stationary and could pan with the officer (Westphal, 2004). These citizens also believed that all patrol vehicles were equipped with cameras; while a majority of vehicles do have cameras, approximately a quarter are still without (Westphal, 2004; IACP, 2004; Reaves, 2010).

Policies and procedures in recording and handling video evidence were identified as key components when adopting patrol vehicle cameras. Laws regulating audio and visual recordings vary depending on the locality. Admissibility of video evidence is dependent on following strict guidelines. For this reason, the 2004 report from the International Association of Chiefs of Police recommended that line officers, as well as administrators and executives, receive proper training on equipment operation and applicable laws (IACP, 2004). Unfortunately, officers interviewed claimed that they rarely received any formal training in the use and operation of their cameras (Westphal, 2004).

\section{Body-Worn Cameras}

Body-worn cameras (BWC) are mobile camera devices worn by law enforcement officers, and are capable of recording audio and video. These wearable devices vary in design. Some are worn on the officer's head, either attached to glasses, hat, or a helmet. Others styles are worn on loose clothing on the torso, or are clipped to a badge or pocket. While the first style of BWC may appear strange and obtrusive, the design has the benefit of using the officer's head as a gyroscope. The extra stabilization is helpful for situations where the officer has to pursue a suspect. While the video captured will still be shaky, it is a huge improvement over a unit that is secured to loose clothing. Also, the camera turns with the officer's head, facing whatever the officer is looking at, so the footage 
captured is from the officer's point of view. Larger batteries fit better into this design style of BWCs; however, the lens of the camera is directed by where the officer points their body. Potentially, important footage may not get recorded because the officer turned their head, but not his or her body, towards the action (National Institute of Justice, 2012).

BWCs are typically more affordable than dashboard camera systems. As of March 2014, the cost of a BWC unit varied from \$120-\$1000 each (National Institute of Justice, 2014). The Kentucky State University Police were able to purchase 14 BWC units with waterproof covers for less than what would have been spent on a single patrol vehicle camera unit (Combs, 2014). Some departments, like the KSU Police Department, may consider using BWCs as a replacement for patrol vehicle cameras, especially agencies with smaller budgets (Combs, 2014; NIJ, 2012).

There are several benefits in mind when implementing the use of BWCs. Much like their counterpart, the patrol vehicle camera, footage collected of officers' interactions with citizens is useful in the judicial process. As stated previously, 91 percent of prosecutors said they used patrol vehicle camera footage as evidence in criminal court proceedings (IACP, 2004). While this research was directed toward the use of patrol vehicle cameras, it is reasonable to believe that these results could be applied to BWCs as well (NIJ, 2012).

Efficiency, effectiveness, and other concerns. BWCs can also act as a deterrent for assaults and other negative actions against officers by citizens as the footage could lead to a stronger case for conviction if an assault were to occur (NIJ, 2012; Combs, 2014). In addition to acting as a deterrent for assaults against officers, BWCs also 
increase the accountability of officers (Combs, 2014). BWCs address a major flaw in the design and implementation of the patrol vehicle camera. It is believed that only 10 percent of police/citizen interactions take place in front of a patrol vehicle. BWCs should be able to shift the benefits of patrol vehicle cameras to scenarios beyond traffic stops (Nash \& Scarberry, 2014). BWCs are more versatile since they remain with the officer during the course of their duties, capturing all interactions that occur during shift (NIJ, 2012; Combs, 2014).

As a result of national pressure to adopt BWCs, empirical research on the technology has become a priority. Current research is particularly encouraging. In a randomized controlled experiment of the Orlando Police department, 46 officers were assigned to wear BWCs while 43 officers did not. The use of BWCs in this experiment displayed a reduction in response-to-resistance incidents by over 53 percent (Jennings, Lynch, \& Fridell, 2015). Similarly, Ariel, Farrar, and Sutherland (2015) conducted an experiment over the course of 12 months. Officers were randomly assigned to shifts that were either equipped with BWCs (the experimental group) or not (the control group). Much like the prior experiment, use-of-force incidents appear to be reduced as a result of BWCs. Force was twice as likely to be used by the control group. The experiments also measured the frequency of citizen complaints. Both studies indicated a significant decrease in complaints within the experimental groups (Ariel, Farrar, \& Sutherland, 2015; Jennings, Lynch, \& Fridell, 2015).

There are some concerns as to how effective BWCs can be based off of the quality of the technology as it stands today. Without a quality piece of equipment capable of working for the course of an entire shift, any benefit of having a BWC will be lost. As 
mentioned before, the location of where a BWC is mounted can change the quality of the footage. The National Institute of Justice (2014) released a market survey of 18 types of BWCs available on the market as of March 2014. Of those 18, only 1 was designed to be worn on the head exclusively, 2 were designed to be worn on the head or torso, and 15 could only be worn on the torso (NIJ, 2014). Other areas that may create potential problems include recording life, built-in data storage, and video quality. Of the 18 models of BWC on the market, the average recording life is 5.4 hours, with the minimum recording 1.5 hours and the maximum recording of 12 hours before the batteries died (NIJ, 2014). This creates a huge problem, especially if the officer interacts with the public on a regular basis. In a similar vein, these models carried anywhere between 1 gigabyte to 64 gigabytes of hard drive space (NIJ, 2014). Depending on the video file quality and subsequent size, the BWC may not be capable of storing an entire shift's worth of footage, forcing officers to return to the department so the files can be downloaded and the BWC unit cleared before returning to their patrols. Video quality is not just affected by the file type or size. Physical characteristics of the BWC, such as focal width or night recording capabilities are also factors that can make or break the value of a BWC recording (NIJ, 2014). Of course, an argument can be made that the absence of such characteristics can actually support officers. If the cameras only functioned as well as an officer's own eyesight, that evidence could support the concept of "reasonableness" as outlined in the Graham v. Connor decision (1989).

As a result of the events in Ferguson, Missouri in 2014, President Barack Obama proposed a \$263 million initiative, including the Body-worn Camera Partnership Program. The program is designed to "provide a 50 percent match to States/localities 
who purchase body-worn cameras and requisite storage" with a projected assisted purchase of 50,000 units (The White House Office of the Press Secretary, 2014). As more agencies adopt the use of BWCs, the amount of detailed empirical research on this subject is very likely to increase.

The versatility of BWCs is also the source of legal scrutiny. In additional to video, these devices record audio, so they fall under varying state and federal regulations on audio recording. Some states require that all parties consent prior to being audio recorded when a warrant is not present (NIJ, 2012). Prior to the adoption of BWC devices, departments must be sure that the devices are not in violation of law. This may mean audio capabilities of BWC will have to be disabled until consent is obtained. Another concern is BWC recording retention regulations and policies, which vary between agencies. While footage of events leading up to and following arrests are likely to be maintained as court evidence, many departments also require that all recordings be maintained for a minimum amount of time in case citizens make a complaint against an officer. Policies also need to control how the footage is uploaded to the department's servers to ensure the chain of custody is not broken or questioned (NIJ, 2012). Defense attorneys will challenge the admission of BWC and dashboard camera recordings based on evidence chain of custody. If there was any question about the process, or any room for doubt about the data handling, the footage would not be admissible in court (IACP, 2004). If officers were allowed to upload their own BWC recordings at the end of their shifts, concerns about corruption and tampering with evidence could cause problems when trying to use the footage in both criminal and civil cases (NIJ, 2012). Some BWC 
models have built-in video safeguards, such as password protection, that help ensure that only authorized personnel upload and remove files from the BWC (NIJ, 2014).

\section{Conclusion}

Technology has had a long and varied history in regards to law enforcement. The changing roles of law enforcement is directly connected to the use of technology. Sometimes, technology was a catalyst for change, in other cases, it was adopted to address specific needs of agencies as a result of changing roles. Each technology covered here are potentially beneficial to law enforcement agencies; they address the need for organizational management, communication, and community and officer accountability. However, each of these technologies are also flawed. Koper, Lum, and Willis (2014) summarized the trouble with the implementation of technology within law enforcement agencies:

(T)echnology's effects are complex and contradictory; technological advances do not always produce straightforward improvements in communication, productivity, job satisfaction, or officers' effectiveness in reducing crime and serving citizens. Desired effects from technology, such as improving clearance rates and reducing crime, may take considerable time to materialize as agencies adapt to new technologies and refine their uses over time (p. 9).

These technologies are not inexpensive, and the infrastructure needed to make the most of the technology's capabilities may not yet exist for the agency or at all. Additionally, the implementation of certain technologies may reduce the perception of the agency as legitimate. While prior research in the area of law enforcement technologies have been essential in illustrating the efficacy of the technology, these studies fail to address the reasons why these technologies are adopted, how they are paid for, nor the role the organization plays in their adoption. In order to truly understand the reasoning behind the implementation of technology in law enforcement agencies, the subject will need to 
be considered outside of the concept of effectiveness, and instead observed from an organizational perspective. 


\section{CHAPTER III \\ THEORETICAL FRAMEWORK \\ Introduction}

In order to understand the decision making process of institutional organizations, one must consider the environment in which they operate. Organizations are complex systems, and operate very differently depending on the ultimate purpose of their existence. Technical organizations, such as businesses, must focus on efficiency and competitiveness in order to remain relevant. Inefficiencies are to be identified and are subsequefixed or removed so the organization can survive. Institutional organizations, such as law enforcement agencies, depend on constituencies, or sovereigns, that hold the key to the organization's survival. These sovereigns may control financial resources that are necessary for organizational health. Some organizations exist solely due to the sovereign's perception of the organization's legitimacy. Regardless of the form of control these sovereigns wield, organizations will make policy decisions based on values held by those sovereigns in order to maintain the health of the organization (Crank, 2003).

Institutional theory has a well-established history as an organizational theory, dating back to the late nineteenth century. Though it fell out of vogue during the early twentieth century, it has seen a resurgence since the late 1970 s under the moniker of neoinstitutional theory (Scott, 2005; Meyer \& Rowan, 1977; Meyer, Scott, \& Deal, 1983). Broadly defined, institutional theory focuses on "the processes and mechanisms by which 
structures, schemas, rules, and routines become established as authoritative guidelines for social behavior" (Scott, 2005, p. 409). Theorists of this perspective state that organizations, such as law enforcement agencies, operate in an institutional environment, and must balance the desires and values of multiple sovereigns, which may contradict each other, in order to retain legitimacy. The result is a complex organizational system of policy, structure, and behavior, designed to keep sovereigns appeased as well as collect on rewards for conformity to desired values.

Within this chapter, the central components of institutional theory will be covered, including the concepts of sovereigns, myths, and complexity. Next, the relevance of institutional theory in association with law enforcement organizations will be explored, including applications of the theory in prior law enforcement research. Finally, this chapter will conclude with a description of how institutional theory will be applied to the current study.

\section{Institutional Theory}

Organizational structure and policy varies depending on the overall goals of the organization. Technical organizations, such as businesses are only successful if they remain competitive against similar organizations. Efficiency and effectiveness in conjunction with the economic bottom line are crucial to a technical organization's survival. Without successful components, these organizations lose legitimacy and will likely be replaced. Some organizations, including government agencies, do not operate in a competitive environment, and are not subject to the same type of influences on organizational behavior. These organizations exist in institutional environments. The 
environment it operates in exists to fulfill a social purpose. In the case of government agencies, this refers to the relevant governmental structure the organization falls under. Institutional organizations primarily differ from technical organizations in that their legitimacy is determined by sovereigns, actors who hold a great deal of power over the welfare of an organization. It is the sovereigns' values that influence the decisionmaking process of institutional organizations, rather than rational decision-making processes as seen in technical organizations. Mastrofski and Uchida (1996) described this process:

Organizations succeed in their well-developed institutional environment to the extent that they conform to structures (procedures, programs, or policies) that are widely accepted as being right even though the relationship of these structures to actual performance is not well established (p. 213).

Sovereigns come in a variety of forms. In the institutional environment of law enforcement agencies, these entities may be members of the community, the government agencies the organization answer to, or other private and public organizations who offer incentives to the law enforcement agency in exchange for conformity (Scott \& Meyer, 1983).

The perceived "correctness" of organizational action is central to the perception of organizational legitimacy; however, the influence of sovereigns within the institutional environment provides other benefits towards organizations as some sovereigns can, and often do, provide rewards for the implementation of "correct structures and processes" (Scott \& Meyer, 1983, p.149). Crank and Langworthy (1992) identified the enabling and constraining effect sovereigns have on an existing organization as a key factor in 
institutional organizational practices, stating that sovereigns are "entities that have the capacity to affect the fundamental well-being of the organization" (p. 342).

"Correctness" or "rightness" of organizational action, behavior, and policy vary in different communities and between different organizations as a result of varying values within the institutional environment. These values are internalized into myths, "understandings of social reality" (Crank, 2003, p. 189) that reflect the values held within the environment. Law enforcement agencies may be subject to several different types of myths, such as the role of police officers as the crime fighter. "Tough on crime" behavior is seen as correct because these actions are in line with the myth of the crime fighter. Within this framework, behaviors are seen as legitimate by organizational sovereigns even if the actions are not fairly implemented. By operating within the framework of its chosen myths, the organization can maintain its legitimacy and support from sovereigns. The myth protects the organization from criticism and informs the choices made by the organization (Crank, 2003; Crank \& Langworthy, 1992).

Crank (2003) identified several interrelated elements of institutionalized organizations including complexity and good faith. Institutional organizations regularly have multiple sovereigns, each holding different values that may contradict each other. The institutional environment contains many sovereign entities, creating a complex environment for the organization to which to operate. It is the responsibility of the organization to satisfy their sovereigns in order to maintain legitimacy. As such, the organization itself must become complex in order to ensure these needs are met. The concept of good faith implies that organization members feel that the actions and behaviors of the organization are inherently right, and actions that fall within the purview 
of this belief are right even if they are not effective. This allows for behavior and examples of unsuccessful policies to be written off a deviation from the norm, that the organization policies are actually beneficial to the community, even in the face of contradictory information (Crank, 2003).

\section{Application to Law Enforcement Organizations}

Often, a normative approach has been applied to research on law enforcement agencies. The normative approach to law enforcement research is more concerned with what agencies should be doing in addition to what they already observe is being done. Researchers believed that using scientific approaches to the study of law enforcement agencies should help identify best policies and behaviors to address crime problems. For example, one research study on the implementation of license plate readers (LPR) found that officers using LPR were more successful in identifying and recovering stolen vehicles, but were less of a deterrent for crime. Since LPRs are automated, officers are able to patrol assigned beats quickly. Officers must manually enter vehicle information into the computer, resulting in slower patrols through their beats. The presence of these officers had a greater deterrent effect on crime as a result. By performing a quasiexperiment, researchers were able to identify that the LPR units were successful in that they helped identify stolen vehicles better than units that lacked the system, as well as areas for patrol improvement (Koper, Taylor, \& Woods, 2003).

Langworthy (1986) presented an alternative perspective with this method of research, stating that these results cannot be generalized between agencies because research has not considered the role of context in the operation of law enforcement agencies. Langworthy's work, The Structure of Police Organizations (1986), is credited 
with connecting the traditional normative approach to neo-institutionalism in regards to law enforcement research (Katz, 2001). He looked to fill a gap in the empirical understanding of police organizations, attempting to develop a theoretical explanation of what agencies do and why. He used data from two surveys to test his theories. He found that causal forces of size, population mobility, population complexity, and type of local government were all significantly related to agency structure; however, these variables were unable to account for variance between agencies (Langworthy, 1986). Since Langworthy's work in the early 1990s, the existing research has consisted of a mix of theoretical and empirical applications (Scott, 2005; Crank, 2003). Much of the research involves the evaluation of community policing (Crank, 1994; Crank \& Langworthy, 1996; Ritti \& Mastrofski, 2002), though other researchers have applied institutional theory to issues such as racial profiling and the development of gang units (Engel, Calnon, \& Bernard, 2001; Katz, 2001).

\section{Theoretical Research}

Crank (1994) applied institutional theory to his analysis of the community policing movement. When considered from a historical context, the community policing movement resulted from criticisms of police policy during the professional era of policing. The community policing movement was an attempt to re-legitimize law enforcement agencies. Originally, liberal influences called for community policing movement to create connections between law enforcement and minority communities (Crank, 1994). At its fruition, the community policing movement initially incorporated two myths, that of the community, a place of traditional values, and the watchman role of the officer, the community protector (Crank, 1994). As the movement developed further 
in the 1980s, the myths of community and watchmen were retailored. The role of watchman was changed from "a police officer who would infrequently invoke formal processes of law, even in the face of law breaking, to one who would arrest to maintain community order, even in the absence of law breaking" (Crank, 1994, p. 341). This was reflective of the new myth "tough on crime," fundamentally changing how agencies operated, even if the name of the movement remained the same. Ritti and Mastroski (2002) expanded on this interpretation of community policing, asserting that the legitimacy of the movement has been taken for granted. They further elaborated on how the movement spread across the nation, where agencies of various compositions adopted community policing practices, starting with dissatisfaction with a problem, consensus on what to do, evaluation of larger agencies' policies for addressing the problem, and institutional transmission of practices to other agencies. In other words, agencies were unhappy with how a problem was being handled, saw others addressing the problem, and chose to do the same. The major takeaway was that pressures to conform led to adoption of policy.

Crank and Langworthy (1996) further analyzed how different levels of political influence changed how law enforcement agencies were structured, particularly focusing on the existence and expansion of middle ranks in agencies on the state, federal, and local levels. This primarily was associated to the concept of organizational complexity within institutional theory. They suggested that the various political influences could increase the number of organizational structures, attempts to control line behavior, and may have an effect on policies and programs that require resources from multiple governmental levels. This assertion is logical. Larger law enforcement agencies are more likely to have 
specialized units and equipment because the funding is available through political and social programs, in addition to the larger tax base. Law enforcement equipment is often expensive. Grant programs or government initiatives help cover the costs for this equipment, though the type of equipment and its purpose is controlled by the sovereign. One such example is the Body-worn Camera Partnership Program. There is little doubt that this program was a result of political pressure. The federal government wishes to increase officer accountability and they are willing to help pay for the equipment to achieve that goal (The White House Office of the Press Secretary, 2014). Similarly, the Department of Homeland Security distributed over two billion dollars in anti-terrorism grants in 2011 (Becker \& Schulz, 2011).

\section{Empirical Research}

Engel, Calnon, and Bernard (2001) analyzed the phenomenon of racial profiling through an institutional theory framework after reviewing other research on racial profiling. Previous research was clear that racial profiling was a real and persistent problem in policing. This is incongruent with the organizational myth of fair justice and impartial enforcement of the law, which is problematic as it opens the agency up for a crisis of legitimacy. What they could not identify within prior research was a theory that would explain this phenomenon. Incorporating the institutional framework, they hypothesized that departments were being rewarded by sovereigns for cracking down on particular kinds of offenders. Their analysis identified that many agencies began utilizing profiling strategies in agency operations following training from the Drug Enforcement Administration. The DEA served as an enabling sovereign. Their involvement in training and adoption of policies and practices opened up avenues to funding and grants, further 
tempting agencies to adopt problematic behaviors. The old organizational myths of fairness and impartiality to would no longer be relevant, and new organization myths would have to be accepted in order to justify these problematic policies.

Research on organizational decisions to develop and adopt new units has also included institutional theory. Katz (2001) applied the theory to research on the development of a gang unit at a single law enforcement agency in the Midwest. Several findings from this study were of particular relevance to institutional theory. First, the law enforcement agency was not involved with the construction of the perception of a gang problem. Alternatively, the community perceived that the community had a gang problem, and in their role as a sovereign, the community applied pressure on the law enforcement agency until the gang unit was developed. Second, the unit would respond to events based off of additional pressure from these sovereigns. Actions taken served a ceremonial role in order to appease the community, rather than actually address the problem. The notion that the unit was developed in order to be actively effective against the perceived problem was challenged in this study, as the development of the unit and its policies were not based off of concerns of efficiency or effectiveness of such units, it was developed as a reaction to pressures from the institutional environment. This reflects back to the work of Mastrofski and Uchida (1996). The organization's success was due to its conformity to desired structures determined by the organization's sovereigns.

The concept of organizational complexity has been conceptualized in various ways. Crank (1990) analyzed the influence of rank structure on arrest rates, identifying that more vertically complex structures appeared to have a stronger influence on the arrest decisions of officers as these agencies had higher arrest rates overall. Chappell, 
MacDonald, and Manz (2006) conceptualized organizational complexity through a series of measures including levels of specialization, "special enforcement activities related to traffic, vice, drug, and drug task-force activities" (p. 294), and administrative complexity, which was calculated as the ratio between the number of field officers and administrative personnel. In this case, there was no identified connection between organizational complexity and arrest rates (Chappell, MacDonald, \& Manz, 2006).

Jurisdictional complexity is more straightforward in its conceptualization. Law enforcement agencies serve communities that vary in composition, often categorized as either urban or rural in research. Institutional theorists have, up to this point, largely ignored the subject of jurisdictional complexity in evaluating law enforcement decisionmaking. This is unfortunate as research on the comparison of rural to urban agencies has shown that there are marked differences in how these agencies operate (Crank, 1990; Falcone, Wells, Weisheit, 2002; Weisheit, Wells, Falcone, 1994). Small-town agencies are less likely to have specialized units. Falcone, Wells, and Weisheit (2002) held up these agencies as "an example of the success of low-tech, nonmilitarized, open systems model" (p. 371) of law enforcement. The contrast between the jurisdictional complexities of these agencies will be of particular interest in the current inquiry.

\section{Application to Current Study}

The adoption of new law enforcement technologies has primarily been the subject of normative research. The focus has been on whether or not these technologies help increase efficiency of law enforcement officers in the course of their duties. The technologies of concern for the current research have been the subject of several of these studies, to mixed results (Gordon et al, 2012; Carter \& Grommon, 2014; Westphal, 2004; 
Nash \& Scarberry, 2014; NIJ, 2014). However, many of these technologies continue to be adopted without consistent empirical support (Reaves, 2010). The question, then, was why do law enforcement organizations continue to adopt costly technologies without empirical support? This study attempted to address this question through institutional theory.

Institutional theory posits that the institutional organization has very little effect on the choices, whether these decisions involve organizational ideologies that guide policy or the decisions to develop specialty units to deal with perceived crime problems (Crank, 1994; Ritti \& Mastroski, 2002; Katz, 2001). These decisions are shaped by the enabling and constraining impact of the institutional environment, specifically the influences of sovereigns. Some of the sovereigns of concern are external government entities, the community in which the agency operates, and even the officers employed at the agency. One type of enabling influence sovereigns may use is through the offer of funding in exchange for conformity to desired programs. One of the main detriments to technology implementation is cost; however, if a sovereign offers money to pay for these technologies, an agency may be more likely to adopt these technologies in their operations.

Acceptance of institutional myths may also have a strong influence on why certain law enforcement agencies adopt specific types of technology. The myth of "technology as a source of safety" may allow agencies to justify the use of technology as it is for the greater good. The role of law enforcement as the "crime fighter" may result in the implementation of new technologies in order to address particular crime problems. Similarly, the myth that technology implementation increases officer efficiency justifies 
technology use. Each of these myths, if accepted by the agency and its sovereigns, appear to be logical and correct, so actions taken within the framework of the myth are seen as legitimate (Scott \& Meyer, 1983; Crank, 2003; Crank \& Langworthy, 1992).

Institutional environments can be incredibly complex in of themselves. As the number of sovereigns increase, the organization has to balance more, potentially contradictory, desires of these sovereigns. As a result, these organizations become more complex themselves (Crank \& Langworthy, 1996; Crank, 2003). By this logic, the organizational and jurisdictional complexity of a law enforcement agency is directly affected by the complexity of the institutional environment. Organizational complexity has been measured in various ways, wholly dependent on the goals of the research. Within this study, the focus remained on the structure of the agency, identifying the horizontal and vertical density of the agency through agency size, rank structure, and divisions. Unfortunately, prior law enforcement research has often been biased towards urban settings (Crank, 1990; Weisheit, 1994). The current study included agencies that serve rural, suburban, and urban populations with the intent to compare the categories of jurisdictional complexity to identify trends in the adoption of technology.

By identifying the presence of institutional myths and outside influences of sovereigns in conjunction with the decision to adopt various technologies, an explanation of agency decision-making may be identified. Using institutional theory to provide a framework to understand these phenomena, this study looked to understand how jurisdictional complexity, organizational complexity, funding, sovereigns, and organizational myths influence the decision to adopt new technologies. The research also attempted to identify what factors, including sovereign influence and subscription to 
institutional myths, serve as the greatest motivators and trends in the decision-making process. 


\section{CHAPTER IV \\ METHODOLOGY}

\section{Introduction}

Current events have led to calls for reforms within the criminal justice system, with various factions supporting differing points of view. Events involving police use of force, specifically cases in Missouri, Maryland, Ohio, New York, and Illinois, have made headlines internationally (Guarino, 2014; Laugland, Glenza, Thrasher \& Lewis, 2014; Swaine \& Laughland, 2015a; Swaine \& Laughland, 2015b; Woolf \& Gosztola, 2015). Communities across the nation are calling for increased accountability of police officers during the course of their duties in addition to increased diversity training and additional equipment such as BWC (Harvard Law Review, 2015; Vicinanzo, 2015). Alternately, recent terrorist incidents in Paris and San Bernardino have led to calls for an increase in funding for police training and equipment (Speed, 2015). One way to address concerns from all of these factions is to increase the amount of technology employed by law enforcement agencies. Unfortunately, normative research on some of these technologies is either non-existent, or has inconsistent results when analyzing the effectiveness of the technology when applied to law enforcement practices (Carter \& Grommon, 2014;

Gordon et al, 2012; Nash \& Scarberry, 2014; NIJ, 2014; Westphal, 2004;). Furthermore, normative research on technology has been limited in scope. External influences of the organization and the environment are rarely, if ever, addressed in these studies, making it 
impossible to generalize results to other agencies. By addressing the variables of organizational and jurisdictional complexity, this research attempted to broaden the research base on law enforcement technology in a way that could be applied to agencies across the United States.

The implementation of technology within law enforcement agencies may have resulted due to external pressures from the institutional environment. The institutional theory framework has been applied to aspects of law enforcement since the 1990s, including analysis of racial profiling (Engel, Calnon, \& Bernard, 2002), the development of gang units (Katz, 2001), and theoretical application to community policing (Crank, 1994; Crank \& Langworthy, 1996; Ritti \& Mastrofski, 2002). All of these studies concluded that the actions taken by the agencies were a result of external influences' desire to address perceived criminal problems and concerns about legitimacy. The current study sought to identify similar trends when considering the implementation of new technology within law enforcement agencies, thereby applying an institutional perspective to the subject of law enforcement technologies, an approach that has not been seen previously.

The data for the current inquiry were derived from a combination of digital and physical surveys sent to a total of 902 law enforcement agencies. A total of 435 of these agencies operate at the county level, the remaining 467 agencies operate at the municipal level. Previous research in the area of technology has focused primarily on individual technologies and empirically testing their efficiency in the field. However, this research has not covered the agency justifications for implementing inefficient technologies. The 
current study looked to expand on examination of technology adoption by exploring these issues within the framework of institutional theory.

The data collected in this exploratory study were analyzed in order to address the following research questions:

1) How does the organizational complexity (i.e. number of officers employed, number of bureaus and divisions, and number of ranks) of a law enforcement agency influence the decision to adopt new technologies?

2) How does the jurisdictional complexity (i.e. whether the community is urban, suburban, or rural) of a law enforcement agency influence the decision to adopt new technologies?

3) Does the presence of funding (i.e. internal and external) influence the likelihood that an agency will adopt new technology?

4) What are some common justifications for adopting records management systems, broadband networking with vehicle computers, long range acoustic devices, patrol vehicle cameras, and body-worn cameras?

By implementing an original study with a large, diverse sample, the current inquiry expanded upon existing research, painting a clearer picture of the effect institutional environments had on law enforcement agencies.

This chapter will outline the research design of the current inquiry, beginning with a description of the setting in which the study sample originated. An explanation of the sample selection criteria will follow. Next, the data collection method will be addressed. In the penultimate section, the dependent and independent variables will be conceptualized. Finally, the statistical data analysis methods will be described. 


\section{Setting}

A number of factors influenced the decision to focus on a particular region of the United States for this study. As the research team is based out of Illinois, the state was of particular interest to the researchers and was included in the selection process by default. When considering the region, the Midwest typically includes the state of Missouri. The heavily publicized coverage of the police shooting of Michael Brown, the subsequent protests, and additional police action was considered to be a threat to the validity of the study if Missouri were to be included. For that reason, the researchers chose to utilize the U.S. Census Bureau's regional designations to select states for the study. The East North Central region of the United States includes Illinois, Wisconsin, Indiana, Michigan, and Ohio. The total number of county and municipal agencies in these five states constituted the population, and the sample was selected from that population (U.S. Census, 2015).

The populations of these five states ranged from approximately 5.8 million people (Wisconsin) to approximately 12.9 million people (Illinois), with between 105 (Wisconsin) to 282.3 (Ohio) persons per square mile (U.S. Census Bureau, 2015). The number of municipal agencies in these states ranges from 405 to 782 , with 2,789 municipal departments listed as operating in the five state area. The number of county agencies operating in each state ranged from 72 to 102, with a total of 437 county law enforcement agencies between the five states.

\section{Sample Selection Criteria}

Due to historical problems with survey response rates from law enforcement agencies, it was decided to sample a large number of municipal and county agencies across the five states. Generalizability of the results from this study was one of the goals 
for this research design. A large enough sample size was a key component in achieving this goal. State agencies were excluded from this study due to the disproportionate amount of funding these agencies receive. The inclusion of these agencies could have resulted in skewed analysis results. Additionally, the generalizability of results for state agencies would have been minimal due to the small number of possible respondents.

A common limitation for survey research in the area of law enforcement is low return rates, resulting in small sample sizes for analysis. In order to counteract this trend, while still maintaining a manageable sample within the time constraints, the researchers decided to approach at least 900 agencies for this study. From the five states identified for inclusion in this study, a potential 2,791 agencies were available for the research sample. It was determined that all county agencies would be included in the initial sample as the total number of counties accounted for approximately of half of the desired sample size $(n=437)$. The researchers desired to include an equal number of municipalities from each of the five states. In order to do so, the total sample size needed to be increased to 902; 93 municipalities were then randomly selected from each state. Prior to randomization, five lists were compiled, separated by state, of every municipality identified from the 2015 National Directory of Law Enforcement Administrators. The separate lists were utilized to reduce the likelihood that a single state would be overrepresented in the final sample. Duplicates were identified and removed. The lists were imported into IBM Statistical Package for the Social Sciences software, after which municipalities were randomly selected for the study though the software's random selection feature. The resulting lists were exported into Excel so contact information could be collected. 


\section{Data Collection}

The survey used in this study was designed and administered in conjunction with additional research on terrorism preparedness. Three separate sections constituted the distributed form: terrorism preparedness, technology, and agency information. Appendix A includes the sections of the survey involving technology and agency information. The survey was distributed in two formats: digital and physical. Digital was the preferred method of distribution, but of the 902 agencies sampled, only 522 valid email addresses were identified. The digital survey was designed and hosted on Illinois State University's in-house survey software, Select Survey. Prior to sending any email to the agencies, they were contacted using a postcard soliciting their participation in the research study. At the beginning of the following week, the survey was deployed, contacting the agencies through email with the link to the digital survey. The agencies were given three weeks to complete the survey before a follow-up email was sent to encourage survey completion if it had not already been done.

As 380 agencies either had no contact information available, or the email addresses provided were not valid, physical surveys were sent to the remaining agencies. The package included a letter explaining the purpose of the study, an informed consent form, the survey booklet, and a business return envelope. The agencies were given a month to return the completed forms before data collection closed so data analysis could be completed on schedule. 


\section{Variables}

\section{Dependent Variables}

For the purposes of this study, the adoption of technologies by law enforcement agencies was measured in two ways: whether or not the technologies were adopted by the agencies, and if adopted, what justifications were given for the adoption. First, surveyed agencies were asked about whether or not they employ five specific technologies individually. The present research was focused on analyzing technologies that fall within the priorities indicated in needs assessments conducted over the last ten years (Gordon et al, 2012; IACP, 2005; Koper, Taylor, \& Kubu, 2009; NIJ, 2010). Additionally, the technologies chosen for the study would have to be already available for use by agencies across the United States. Law enforcement agencies deploy many different types of technology on a daily basis, many of which fall into the identified areas of interest. It is particularly difficult to gather data on all aspects of law enforcement technology. Since the current research survey took place alongside unrelated research, the scope of this study remained narrow. For the purposes of brevity, only five technologies were chosen for this research study: computer-based records management systems, broadband networking with vehicle computer systems, long range acoustic devices, patrol vehicle cameras, and body-worn cameras. Agencies could have adopted up to five different types of technology. The adoption variable was coded in two ways. Initially, this variable was separated by the type of technology (RMS, broadband networking, LRAD, patrol vehicle camera, BWC), and was coded as yes (1) or no (0). The second version of the variable was coded by combining the data on a scale of 0 to 5 , depending on the number of adopted technologies that were identified. Analysis of these variables provided both a 
general and detailed overview of the subject, allowing for the identification of trends on the subject of technology as a whole and by specific technology.

Second, agencies that indicated that they had adopted these technologies were asked to indicate the purposes the technology served for their agency. The possible choices included concerns of officer safety, community safety, efficiency, federal and state requirements, and in order to address a crime problem. Each of these requirements were categorized as organizational myths or as self-identified influences of organizational sovereigns (Crank, 2003; Crank \& Langworthy, 1992). The myths of concern in this study are technology as a source of officer and community safety, the role of police as the crime fighter, and technology's influence on officer efficiency. The sovereigns identified by this survey question include the federal and state governments. If administrators indicated that the agency lacked the technology, agency administrators were asked whether or not they desire the technology at all. This question was not anticipated to be used for the current analysis, as it did not address any of the research questions pertinent to this inquiry. However, it may help create context for future analysis.

\section{Independent Variables}

According to Crank and Langworthy (1996), institutions tend to mirror the complexity of the environment in which they operate. By reversing that logic, jurisdictional and organizational complexity may indicate a complex institutional environment, where the presence of a larger number of sovereigns may establish influence on the organization. Jurisdictional complexity was defined as the density of the community population that the law enforcement agency serves. In the survey, agency administrators were asked to categorize their jurisdiction as rural, suburban, or urban. 
Ultimately, responses were coded as rural (1) or suburban/urban (2) due to the low number of agencies that identified their jurisdictions as urban.

Organizational complexity is described as the structure of the agency itself. Agency administrators were asked questions regarding the composition of their agencies, including the number of sworn officers employed by the organization, the number of rank levels in the agency, as well as the number of divisions and bureaus utilized. The number of sworn officers variable was further refined by calculating the ratio of sworn officers to every 1000 citizens. In order to determine if organizational complexity had an influence on the adoption of technology as a whole, as well evaluate the effect the variable's individual components had on the adoption of technology, organizational complexity was evaluated in two ways. First, the individual components were compared to the dependent variables. Second, the variables were combined into a factor score measuring the concept of organizational complexity as a whole. Measurement validity of the factor score was confirmed through a factor analysis with Varimax rotation.

The final independent variable that may influence the adoption of technologies was funding sources. Sovereigns can enable organizations who adopt desired processes and policies through the use of rewards. Oftentimes these rewards come in the form of financial support (Scott \& Meyer, 1983). Surveyed administrators were asked about their sources for funding equipment, specifically identifying if they received funding from internal sources or external sources. Administrators were able to select more that one of these categories, so internal and external funding were analyzed as separate variables, coded as yes (1) or no (2). 


\section{Data Analysis}

The results from the digital survey were exported from the Select Survey application into an Excel file format for clean-up. Data from the physical surveys were entered manually into a separate Excel file as the responses arrive. Due to concerns about time constraints, the research team stopped accepting surveys for data entry after a month of the survey's distribution. Additional survey responses received after the deadline were retained for data entry after the current study was completed. Once the data were cleaned in Excel, the files were transferred into SPSS for data analysis.

Univariate analyses were conducted to identify initial trends and potential problems within the data set. The dependent variable of adoption of technology and the independent variables of organizational complexity, jurisdictional complexity, and funding were analyzed through descriptive statistics. Frequencies were used to analyze the justifications for technology implementation identified by agencies, addressing the fourth research question.

A series of bivariate analyses were completed for the first three research questions. The organizational complexity factors were compared to the adoption of individual technologies through $t$-tests. As each of the variables were coded dichotomously, jurisdictional complexity, internal funding, and external funding were compared to each technology through a series of chi-square tests. Bivariate correlation was used to identify significant relationships between the variables of the technology adoption index, jurisdictional complexity, internal funding, external funding, and the organizational complexity factor score. Multivariate analysis was approached through the 
implementation of ordinary least squares (OLS) regression, which utilized the technology adoption index and organizational complexity factor score for analysis.

Prior research has indicated that well-known policy reforms in criminal justice can be credited to the institutional environment the organizations operate in, rather than the efficiency of the policies. The policies, as well as organizational legitimacy, are derived from the perceived correctness of the actions. This effect is credited to the influence of sovereigns in the institutional environment, as well as the adoption of organizational myths that allow organizations to justify their actions as correct. In regards to the subject of law enforcement technology, agencies are subject to multiple types of sovereigns with various influences on the organization. Current events have resulted in calls for criminal justice reform from within the communities, such as the black lives matter movement. Renewed fears of terrorism alternately have called for increases in police action. Federal organizations, such as the NIJ, OST, and NLECTC, have conducted normative, "what works," research, but they also encourage the adoption of new technology by offering grants and training to agencies who choose to adopt new technologies, further enabling the agencies while also encouraging the adoption of institutional myths. The current study looked to empirically support institutional theory within the context of technology implementation. 


\section{CHAPTER V}

\section{RESULTS}

\section{Introduction}

Prior research in the area of law enforcement technology has largely focused on the effectiveness of various technologies, ignoring the context and environments in which these technologies operate. The current research study was designed to elaborate on prior law enforcement technology research through the lens of institutional theory in order to consider multiple contextual factors that may influence the decision to implement technology beyond the efficiency of the equipment. Ultimately, this study looked to consider the factors: organizational complexity (i.e. number of officers employed, number of bureaus and divisions, and number of ranks), jurisdictional complexity (i.e. whether the community is urban, suburban, or rural), funding (e.g. grants and private funds), and justifications for implementation to determine if these variables have influence on the decision to adopt records management systems, broadband networking with mobile computer terminals, long range acoustic devices, patrol vehicle cameras, and body-worn cameras in a law enforcement setting.

This chapter includes various statistical analyses in order to address the posited research questions. First, the dependent and independent variables were analyzed through descriptive statistics. Next, a series of bivariate analyses, including $t$-tests and chi square tests, were completed to determine the influence of organizational complexity, 
jurisdictional complexity, and funding sources on the adoption of the individual technologies. Finally, regression analysis was used to determine the influence of organizational complexity, jurisdictional complexity, and funding sources on the adoption of multiple technologies. A summary of significant statistical findings will end this chapter.

\section{Univariate Analysis}

Descriptive statistics for six of the dependent and four independent variables are displayed in Table 1. The dependent variable of adoption of technology was measured both individually and as a part of an index. Between 103 and 106 agencies returned valid responses to the survey questions regarding the individual technologies. RMS was implemented the most often $(\bar{x}=0.86, \mathrm{SD}=0.35)$, followed by broadband networking $(\bar{x}$ $=0.84, \mathrm{SD}=0.37)$ and patrol vehicle cameras $(\bar{x}=0.79, \mathrm{SD} 0.41)$. LRAD was implemented the least $(\bar{x}=0.05, \mathrm{SD}=0.22)$ followed by $\mathrm{BWC}(\bar{x}=0.33, \mathrm{SD}=0.47)$. The adoption of technology index was computed to measure the total number of technologies used by each respondent, and included data from 100 agencies $(\bar{x}=2.88$, $\mathrm{SD}=1.01)$

Organizational complexity was measured using three components: the ratio of the number of sworn officers to every 1000 citizens served, the number of ranks within the department, and the number of divisions in each department. A factor analysis with Varimax rotation was implemented. The analysis yielded one factor which explained 59 percent of the variance $($ Eigenvalue $=1.77$ ). Based off of valid data provided by 104 agencies, the agencies had an average of 2.32 sworn officers to every 1000 citizens served in their jurisdictions, ranging from 0.10 to 17.57 officers to 1000 citizens $(\mathrm{SD}=$ 
2.72). While the minimum and maximum values were perceived as particularly low and high, respectively, the mean was close to the national average. As such, it was felt that the outliers were not a significant concern. Data from 105 respondents were used to calculate the number of ranks $(\bar{x}=3.90, \mathrm{SD}=2.00)$ and provided divisional data $(\bar{x}=$ $2.68, \mathrm{SD}=2.88)$

Table 1

\section{Descriptive Statistics}

\begin{tabular}{llllll}
\hline Variables & $\mathrm{N}$ & Mean & SD & Min & Max \\
\hline Dependent Variable & & & & & \\
Adoption of Technology & 100 & 2.88 & 1.01 & 0 & 5 \\
$\quad$ RMS & 105 & 0.86 & 0.35 & 0 & 1 \\
$\quad 104$ & 0.84 & 0.37 & 0 & 1 \\
$\quad$ Broadband & 106 & 0.79 & 0.41 & 0 & 1 \\
$\quad$ Patrol Camera & 103 & 0.05 & 0.22 & 0 & 1 \\
$\quad$ LRAD & 105 & 0.33 & 0.47 & 0 & 1 \\
$\quad$ BWC & & & & & \\
Independent Variables & & & & & \\
Organizational Complexity & 103 & 0.00 & 1.00 & -2.72 & 3.39 \\
$\quad$ Factor Score & 104 & 2.32 & 2.72 & 0.10 & 17.57 \\
$\quad$ Sworn Officer to 1000 Citizen & 105 & 3.90 & 2.00 & 0.00 & 10 \\
$\quad$ Number of Ranks & 105 & 2.68 & 2.88 & 0.00 & 18 \\
$\quad$ Number of Divisions & 106 & 0.37 & 0.48 & 0 & 1 \\
Jurisdictional Complexity & & & & & \\
Funding & 97 & 0.94 & 0.24 & 0 & 1 \\
$\quad$ Internal & 97 & 0.61 & 0.49 & 0 & 1 \\
$\quad$ External & & & & &
\end{tabular}

Jurisdictional complexity was assessed through self-determined categorization $(0$ $=$ Rural, $1=$ Suburban/Urban). The majority of the respondents identified their jurisdictions as rural in complexity $(\bar{x}=0.37, \mathrm{SD}=0.48)$. Funding was categorized as internal and external, referring to the source of the funding for these technologies. Only 97 agencies answered questions regarding the funding of technology. A majority of these 
agencies indicated the use of internal funding $(\bar{x}=0.94, \mathrm{SD}=0.24)$, and only a slight majority indicated the use of external funding $(\bar{x}=0.61, \mathrm{SD}=0.49)$.

The final dependent variable addresses research question number 4, identifying common justifications for the adoption of the technologies of RMS, broadband networking, LRAD, patrol cameras, and BWC. The survey questions regarding these justifications were only addressed if the agency indicated the current use of the technology in question, ranging from five to ninety agencies answering in the affirmative. Table 2 displays the frequencies of each of these justifications for the agencies who indicated the technology was currently used by the agency. These justifications were based off of institutional theory's concepts of sovereign influence and organizational myths.

Agencies who identified their use of RMS systems $(n=90)$ were most likely to indicate efficiency as a motivator for adoption (94.4\%), followed by officer safety (67.8\%), community safety (62.2\%), satisfaction of state requirements (50.0\%) and federal requirements (35.6\%), and to address a crime problem (33.3\%). Broadband networking was the second most common technology utilized by responding agencies $(n=87)$ with the most common motivators of efficiency (97.6\%), officer safety (83.5\%), and community safety $(63.5 \%)$. While some agencies did answer in the affirmative, the remaining motivators of federal and state requirements as well as the address of a crime problem were represented less than half of the responding agencies $(18.8 \%, 27.1 \%$, and 23.8\% respectively). Patrol vehicle cameras were used by 83 of the 106 responding agencies. Officer safety (96.4\%), community safety (85.5\%), and efficiency (75.9\%) were identified as the primary motivators for the adoption. A minority of agencies 
indicated that federal requirements $(13.3 \%)$, state requirements $(18.1 \%)$, and crime problems $(33.7 \%)$ were motivating factors on the decision to adopt the cameras.

Table 2

Justification Frequencies

\begin{tabular}{|c|c|c|}
\hline Technology & Yes & No \\
\hline \multicolumn{3}{|l|}{ RMS (n = 90) } \\
\hline Efficiency & $85(94.4 \%)$ & $5(5.6 \%)$ \\
\hline Officer Safety & $61(67.8 \%)$ & $29(32.2 \%)$ \\
\hline Community Safety & $56(62.2 \%)$ & $34(37.8 \%)$ \\
\hline State Requirements & $45(50.0 \%)$ & $45(50.0 \%)$ \\
\hline Federal Requirements & $32(35.6 \%)$ & $58(64.4 \%)$ \\
\hline Crime Problem & $30(33.3 \%)$ & $60(66.7 \%)$ \\
\hline \multicolumn{3}{|l|}{ Broadband $(n=87)$} \\
\hline Efficiency & $83(97.6 \%)$ & $2(2.4 \%)$ \\
\hline Officer Safety & $71(83.5 \%)$ & $14(16.5 \%)$ \\
\hline Community Safety & $54(63.5 \%)$ & $31(36.5 \%)$ \\
\hline State Requirements & $23(27.1 \%)$ & $62(72.9 \%)$ \\
\hline Crime Problem & $20(23.8 \%)$ & $64(76.2 \%)$ \\
\hline Federal Requirements & $16(18.8 \%)$ & $69(82.2 \%)$ \\
\hline \multicolumn{3}{|l|}{ Patrol Cameras $(\mathrm{n}=83)$} \\
\hline Officer Safety & $80(96.4 \%)$ & $3(3.6 \%)$ \\
\hline Community Safety & $71(85.5 \%)$ & $12(14.5 \%)$ \\
\hline Efficiency & $63(75.9 \%)$ & $20(24.1 \%)$ \\
\hline Crime Problem & $28(33.7 \%)$ & $55(66.3 \%)$ \\
\hline State Requirements & $15(18.1 \%)$ & $68(81.9 \%)$ \\
\hline Federal Requirements & $11(13.3 \%)$ & $72(86.7 \%)$ \\
\hline \multicolumn{3}{|l|}{$\mathrm{BWC}(\mathrm{n}=35)$} \\
\hline Officer Safety & $30(85.7 \%)$ & $5(14.3 \%)$ \\
\hline Efficiency & $29(85.3 \%)$ & $5(14.7 \%)$ \\
\hline Community Safety & $28(82.4 \%)$ & $6(17.6 \%)$ \\
\hline Crime Problem & $13(37.1 \%)$ & $22(62.9 \%)$ \\
\hline State Requirements & $6(17.1 \%)$ & $29(82.9 \%)$ \\
\hline Federal Requirements & $4(11.4 \%)$ & $31(88.6 \%)$ \\
\hline \multicolumn{3}{|l|}{ LRAD $(n=5)$} \\
\hline Officer Safety & $2(50.0 \%)$ & $2(50.0 \%)$ \\
\hline Community Safety & $2(50.0 \%)$ & $2(50.0 \%)$ \\
\hline Efficiency & $0(0 \%)$ & $4(100.0 \%)$ \\
\hline State Requirements & $0(0 \%)$ & $4(100.0 \%)$ \\
\hline Federal Requirements & $0(0 \%)$ & $4(100.0 \%)$ \\
\hline Crime Problem & $0(0 \%)$ & $4(100.0 \%)$ \\
\hline
\end{tabular}


Less than half of the responding agencies indicated the use of BWC $(n=35)$ and LRAD ( $\mathrm{n}=5)$. Officer safety $(85.7 \%)$, efficiency $(85.3 \%)$, and community safety $(82.4 \%)$ were the most common motivators for the use of BWC. Crime problems were considered a motivator by $37.1 \%$ of the agencies, with state and federal requirements represented by $17.1 \%$ and $11.4 \%$, respectively. Of the few agencies who indicated their use of LRAD, community and officer safety were the only motivations chosen, each representing $50 \%$ of the respondents. Due to the particularly small sample of agencies using LRAD, any further analysis of the individual technology was forgone; however, it still factored into the adoption index variable used in regression analysis.

Overall, officer safety, efficiency, and community safety appeared to be the most common justifications for technology use as they were ranked as the top three in every iteration of the univariate analysis. Federal requirements had the least effect on the implementation of technology, ranking last in four of the five iterations of the analysis

\section{Bivariate Analysis}

The current research study was designed to address several research questions, the first being how does the organizational complexity (i.e. number of officers employed, number of bureaus and divisions, and number of ranks) of a law enforcement agency influence the decision to adopt new technologies? In order to identify whether or not factors of organizational complexity play a role in the adoption of law enforcement technology, a series of independent-paired $t$-tests were performed comparing the values of the adoption status of the various technologies (yes or no) to the means of the independent variables (sworn officer to citizen ratio, number of ranks, and number of divisions). Results from t-test analysis of the organizational complexity factors indicated 
significant positive relationships between RMS adoption and the complexity factors of rank and division totals (Table 3). Agencies with a higher number of ranks were more likely to have adopted RMS technology $(\mathrm{M}=4.10, \mathrm{SD}=2.03)$ than agencies with fewer rank levels reported $(\mathrm{M}=2.67, \mathrm{SD}=1.35), t(102)=2.64, p=0.01$. The results also indicated that agencies with a larger number of reported divisions were more likely to adopt RMS technology $(\mathrm{M}=2.93, \mathrm{SD}=3.00)$ than agencies with fewer reported divisions $(\mathrm{M}=1.07, \mathrm{SD}=1.27), t(102)=2.28, p=0.03$. The remaining variable of officer to citizen ratio showed no statistically significant relationship to the adoption of RMS technology.

Some clarification is necessary regarding the results of the $t$-test observing the relationship between organizational complexity factors and the adoption of broadband technology. As indicated in Table 4, the only variable of significance is that of organization divisions. The results indicated that agencies with a greater number of divisions were more likely to adopt broadband networking technology $(\mathrm{M}=2.93, \mathrm{SD}=$ 3.06) than agencies with fewer divisions ( $\mathrm{M}=1.38, \mathrm{SD}=1.31)$, the actual $p$ value was nearly equal to the level of significance, $t(101)=2.00, p=0.049$. Alternately, while extremely close to the level of significance, the $p$ value for the analysis of sworn officer to citizen ratio was slightly over, $p=0.052$. If a larger sample had been available, it is fairly likely that the analysis of officer to citizen ratio and broadband technology would have indicated significance. When the organizational complexity factors were tested against the adoption statuses of patrol vehicle cameras and BWC, no statistically significant relationships were identified. These data are found in Table 5 and Table 6 , respectively. 
Table 3

Relationship Between Organizational Complexity Factors and RMS Adoption

\begin{tabular}{lccccccc}
\hline Org Complexity Factor & & $\mathrm{n}$ & Mean & SD & df & t-test & $p$ \\
\hline Sworn Officer Ratio & & & & & & & \\
& Yes & 88 & 2.16 & 2.77 & 101 & -1.09 & 0.28 \\
& No & 15 & 2.98 & 2.10 & & & \\
Number of Ranks & Yes & 89 & 4.10 & 2.03 & 102 & 2.64 & $0.01^{* *}$ \\
& No & 15 & 2.67 & 1.35 & & & \\
Number of Divisions & & & & & & & \\
& Yes & 90 & 2.93 & 3.00 & 102 & 2.28 & $0.03^{*}$ \\
& No & 14 & 1.07 & 1.27 & & & \\
\hline
\end{tabular}

$* * p<.01$ level, $* \mathrm{p}<0.05$ level (2-tailed)

Table 4

Relationship Between Organizational Complexity Factors and Broadband Adoption

\begin{tabular}{lccccccc}
\hline Org Complexity Factor & & $\mathrm{n}$ & Mean & SD & df & t-test & $p$ \\
\hline Sworn Officer Ratio & & & & & & & \\
& Yes & 86 & 2.04 & 2.28 & 101 & -1.97 & 0.05 \\
No & 17 & 3.42 & 4.05 & & & \\
Number of Ranks & Yes & 86 & 4.06 & 2.07 & 101 & 1.79 & 0.08 \\
& No & 17 & 3.12 & 1.41 & & & \\
Number of Divisions & & & & & & & \\
& Yes & 87 & 2.93 & 3.06 & 101 & 2.00 & $0.05^{*}$ \\
& No & 16 & 1.38 & 1.31 & & & \\
\hline
\end{tabular}

$* p<0.05$ level (2-tailed)

Table 5

Relationship Between Organizational Complexity Factors and Patrol Camera Adoption \begin{tabular}{lllllll}
\hline Org Complexity Factor & $\mathrm{n}$ & Mean & SD & df & t-test & $p$
\end{tabular} Sworn Officer Ratio

$\begin{array}{lllllll}\text { Yes } & 82 & 2.40 & 2.90 & 102 & 0.58 & 0.56 \\ \text { No } & 22 & 2.02 & 1.92 & & & \end{array}$

Number of Ranks

$\begin{array}{lllllll}\text { Yes } & 83 & 3.93 & 1.99 & 103 & 0.32 & 0.75 \\ \text { No } & 22 & 3.77 & 2.07 & & & \end{array}$

Number of Divisions

\begin{tabular}{lllllll} 
Yes & 83 & 2.63 & 2.61 & 103 & -0.34 & 0.73 \\
No & 22 & 2.83 & 3.82 & & & \\
\hline
\end{tabular}


Table 6

\begin{tabular}{|c|c|c|c|c|c|c|c|}
\hline Org Complexity Factor & & $\mathrm{n}$ & Mean & SD & df & t-test & $p$ \\
\hline \multicolumn{8}{|l|}{ Sworn Officer Ratio } \\
\hline & Yes & 35 & 2.80 & 3.94 & 101 & 1.28 & 0.20 \\
\hline & No & 68 & 2.08 & 1.82 & & & \\
\hline \multicolumn{8}{|l|}{ Number of Ranks } \\
\hline & Yes & 35 & 3.63 & 1.82 & 102 & -1.00 & 0.32 \\
\hline & No & 69 & 4.04 & 2.09 & & & \\
\hline \multicolumn{8}{|l|}{ Number of Divisions } \\
\hline & Yes & 34 & 2.29 & 2.47 & 102 & -0.95 & 0.34 \\
\hline & No & 70 & 2.87 & 3.08 & & & \\
\hline
\end{tabular}

The second research question enquires as to the role jurisdictional complexity has in the decision to adopt technology. Jurisdictional complexity was coded on a dichotomous nominal scale (rural, suburban/urban), much like the individual technology adoption variables (yes/no). For that reason, chi square analysis was utilized to address the relationship between the variables. Of the four comparisons, the only chi square test that showed a significant relationship was that between jurisdictional complexity and broadband networking technology, $\chi^{2}(1, \mathrm{n}=104)=5.38, p<0.05$. Rural jurisdictions are less likely to have broadband networking technology than suburban and urban jurisdictions (Table 8). Jurisdictional complexity appeared to have no statistically significant effect on the adoption of RMS (Table 7), patrol vehicle cameras (Table 9), or BWC (Table 10) technologies.

One research question remains unaddressed: does the presence of funding influence the likelihood that an agency will adopt new technology? The variables for internal and external funding were analyzed separately as the categories were not mutually exclusive. Like jurisdictional complexity, the internal and external funding 
Table 7

Relationship Between Jurisdictional Complexity and Adoption of RMS

\begin{tabular}{llll}
\hline & \multicolumn{3}{c}{ RMS Adoption } \\
\hline Jurisdictional Complexity & Yes & No & Total \\
Rural & $55(82.1 \%)$ & $12(17.9 \%)$ & $67(100 \%)$ \\
Suburban/Urban & $35(92.1 \%)$ & $3(7.9 \%)$ & $38(100 \%)$ \\
\hline
\end{tabular}

Note. $\chi^{2}=1.99, p=0.16, \mathrm{n}=105, \mathrm{df}=1$. Row percentages are shown next to observed cell counts.

Table 8

Relationship Between Jurisdictional Complexity and Adoption of Broadband Networking

\begin{tabular}{llll}
\hline \multicolumn{3}{c}{ Broadband Adoption } \\
\hline Jurisdictional Complexity & Yes & No & Total \\
Rural & $51(77.3 \%)$ & $15(10.8 \%)$ & $66(100 \%)$ \\
Suburban/Urban & $36(94.7 \%)$ & $6.2(5.3 \%)$ & $38(100 \%)$ \\
\hline
\end{tabular}

Note. $\chi^{2}=5.38, p=0.02^{*}, \mathrm{n}=104, \mathrm{df}=1$. Row percentages are shown next to observed cell counts.

Table 9

Relationship Between Jurisdictional Complexity and Adoption of Patrol Vehicle Cameras

\begin{tabular}{llll}
\hline \multicolumn{3}{c}{ Patrol Camera Adoption } \\
\hline Jurisdictional Complexity & Yes & No & Total \\
Rural & $52(77.6 \%)$ & $15(22.4 \%)$ & $67(100 \%)$ \\
Suburban/Urban & $32(82.1 \%)$ & $7(17.9 \%)$ & $39(100 \%)$ \\
\hline
\end{tabular}

Note. $\chi^{2}=0.30, p=0.59, \mathrm{n}=106, \mathrm{df}=1$. Row percentages are shown next to observed cell counts.

Table 10

Relationship Between Jurisdictional Complexity and Adoption of BWC

\begin{tabular}{llll}
\hline \multicolumn{3}{c}{ BWC Adoption } \\
\hline Jurisdictional Complexity & Yes & No & Total \\
Rural & $24(35.8 \%)$ & $43(64.2 \%)$ & $67(100 \%)$ \\
Suburban/Urban & $11(28.9 \%)$ & $27(71.1 \%)$ & $38(100 \%)$ \\
\hline
\end{tabular}

Note. $\chi^{2}=0.52, p=0.47, \mathrm{n}=105, \mathrm{df}=1$. Row percentages are shown next to observed cell counts. 
variables were coded on a dichotomous nominal scale (yes or no regarding whether that type of funding was provided), so chi square tests were also implemented to test the potential relationships between funding and the adoption of individual technology.

Following eight separate analyses comparing internal funding to the various technology, as well as external funding to the individual technologies, a significant relationship was determined to exist between internal funding and the adoption of patrol vehicle cameras, $\chi^{2}(1, \mathrm{n}=97)=4.67, p<0.05$, and the adoption of BWC, $\chi^{2}(1, \mathrm{n}=96)=6.42, p<0.05$. Table 13 displays the results for the patrol vehicle camera analysis and Table 14 includes the results for the BWC analysis. While no relationship was found between the presence of internal funding and the remaining technologies of RMS and broadband networking, the individual statistical analyses can be found in Tables 11 and 12. Similarly, no statistical relationship could be identified in any of the analyses involving the presence of external funding. The resulting data is displayed in Tables 15, 16, 17 and 18.

Table 11

Relationship Between Internal Funding and Adoption of RMS

\begin{tabular}{llll}
\hline & \multicolumn{3}{c}{ RMS Adoption } \\
\hline Internal Funding & Yes & No & Total \\
Yes & $79(87.8 \%)$ & $11(12.2 \%)$ & $90(100 \%)$ \\
No & $4(66.7 \%)$ & $2(33.3 \%)$ & $6(100 \%)$ \\
\hline Note. $\chi^{2}=2.14, p=0.14, \mathrm{n}=96, \mathrm{df}=1$. Row percentages are shown next to observed cell counts.
\end{tabular}


Table 12

Relationship Between Internal Funding and Adoption of Broadband Networking

\begin{tabular}{llll}
\hline & \multicolumn{3}{c}{ Broadband Adoption } \\
\hline Internal Funding & Yes & No & Total \\
Yes & $79(87.8 \%)$ & $11(12.2 \%)$ & $90(100 \%)$ \\
No & $4(66.7 \%)$ & $2(33.3 \%)$ & $6(100 \%)$ \\
\hline
\end{tabular}

Note. $\chi^{2}=2.14, p=0.14, \mathrm{n}=96, \mathrm{df}=1$. Row percentages are shown next to observed cell counts.

Table 13

Relationship Between Internal Funding and Adoption of Patrol Vehicle Cameras

\begin{tabular}{llll}
\hline & \multicolumn{3}{c}{ Patrol Camera Adoption } \\
\hline Internal Funding & Yes & No & Total \\
Yes & $77(84.6 \%)$ & $14(15.4 \%)$ & $91(100 \%)$ \\
No & $3(50.0 \%)$ & $3(50.0 \%)$ & $6(100 \%)$ \\
\hline
\end{tabular}

Note. $\chi^{2}=4.67, p=0.03^{*}, \mathrm{n}=97, \mathrm{df}=1$. Row percentages are shown next to observed cell counts.

Table 14

Relationship Between Internal Funding and Adoption of BWC

\begin{tabular}{llll}
\hline & \multicolumn{3}{c}{ BWC Adoption } \\
\hline Internal Funding & Yes & No & Total \\
Yes & $29(32.2 \%)$ & $61(67.8 \%)$ & $90(100 \%)$ \\
No & $5(83.3 \%)$ & $1(16.7 \%)$ & $6(100 \%)$ \\
\hline
\end{tabular}

Note. $\chi^{2}=6.42, p=0.01 * *, \mathrm{n}=96, \mathrm{df}=1$. Row percentages are shown next to observed cell counts.

Table 15

Relationship Between External Funding and Adoption of RMS

\begin{tabular}{lccl}
\hline & \multicolumn{3}{c}{ RMS Adoption } \\
\hline External Funding & Yes & No & Total \\
Yes & $49(84.5 \%)$ & $9(15.5 \%)$ & $67(100 \%)$ \\
No & $34(89.5 \%)$ & $4(10.5 \%)$ & $38(100 \%)$ \\
\hline Note. $\chi^{2}=0.49, p=0.49, \mathrm{n}=96, \mathrm{df}=1$. Row percentages are shown next to observed cell counts.
\end{tabular}


Table 16

Relationship Between External Funding and Adoption of Broadband Networking

\begin{tabular}{lccc}
\hline & \multicolumn{3}{c}{ Broadband Adoption } \\
\hline External Funding & Yes & No & Total \\
Yes & $51(86.4 \%)$ & $8(13.6 \%)$ & $59(100 \%)$ \\
No & $32(86.5 \%)$ & $5(13.5 \%)$ & $37(100 \%)$ \\
Note. $\chi^{2}=0.00, p=1.00, \mathrm{n}=96, \mathrm{df}=1$. Row percentages are shown next to observed cell counts.
\end{tabular}

Table 17

Relationship Between External Funding and Adoption of Patrol Vehicle Cameras

\begin{tabular}{llll}
\hline \multicolumn{3}{c}{ Patrol Camera Adoption } \\
\hline External Funding & Yes & No & Total \\
Yes & $46(78.0 \%)$ & $13(22.0 \%)$ & $59(100 \%)$ \\
No & $34(89.5 \%)$ & $4(10.5 \%)$ & $38(100 \%)$ \\
\hline
\end{tabular}

Note. $\chi^{2}=2.12, p=0.15, \mathrm{n}=97, \mathrm{df}=1$. Row percentages are shown next to observed cell counts.

Table 18

Relationship Between External Funding and Adoption of BWC

\begin{tabular}{llll}
\hline \multicolumn{3}{c}{ BWC Adoption } \\
\hline External Funding & Yes & No & Total \\
Yes & $21(36.2 \%)$ & $37(63.8 \%)$ & $67(100 \%)$ \\
No & $13(34.2 \%)$ & $25(65.8 \%)$ & $38(100 \%)$ \\
\hline
\end{tabular}

Note. $\chi^{2}=0.04^{*}, p=0.84, \mathrm{n}=96, \mathrm{df}=1$. Row percentages are shown next to observed cell counts.

Bivariate correlation analysis was conducted to identify significant relationships between the variables of the technology adoption index, jurisdictional complexity, internal funding, external funding, and organizational complexity (See Table 19). No significant relationship was identified between the dependent variable of technology adoption and any of the independent variables; however, several of the independent variables displayed correlations to each other. The Pearson correlation coefficient for 
jurisdictional complexity and external funding shows a statistically significant positive linear relationship between the two variables, $\mathrm{r}(97)=0.26, p=0.01$, two-tailed.

Similarly, the Pearson correlation coefficient for jurisdictional complexity and organizational complexity also shows a significant positive linear relationship, $\mathrm{r}(103)=$ $0.35, p=0.00$, two-tailed. The Pearson correlation coefficient for internal funding has a weak negative linear relationship with external funding, $\mathrm{r}(97)=-0.21, p=0.04$, twotailed, and a positive linear relationship with organizational complexity, $\mathrm{r}(95)=0.28, p=$ 0.01, two-tailed.

Table 19

Bivariate Correlation Matrix

\begin{tabular}{llllll}
\hline Measure & 1 & 2 & 3 & 4 & 5 \\
\hline 1. Technology Adoption & - & & & & \\
2. Jurisdictional Complexity & 0.15 & - & & & \\
3. Internal Funding & -0.01 & 0.12 & - & & \\
4. External Funding & -0.07 & $0.26^{*}$ & $-0.21^{*}$ & - & \\
5. Organizational Complexity & 0.09 & $0.35^{* *}$ & $0.28^{* *}$ & 0.09 & - \\
\hline *Indicates correlation significant at $p<.05$ level. & & & \\
**Indicates correlation significant at $p<.01$ level. & & &
\end{tabular}

\section{Multivariate Analysis}

Before an ordinary least squares (OLS) regression could be performed and analyzed, several assumptions needed to be met through a series of regression diagnostics. First, the data set had to be tested to ensure the absence of multicollinearity between variables. The correlation matrix of the regression output displayed no variables with a correlation higher than 0.08 , falling well within the limit of 0.70 . Table 20 displays further multicollinearity diagnostics. If multicollinearity were to exist in this analysis, the 
tolerance levels would approach a zero value; this is not displayed in the current diagnostic. Additionally, VIF would display values of 2.0 or higher in the presence of multicollinearity. The VIF values of the current diagnostic range from 1.15 to 1.28 , suggesting the absence, or vary low risk of multicollinearity.

Table 20

Multicollinearity Diagnostics

\begin{tabular}{lll}
\hline Variable & Tolerance & VIF \\
\hline Jurisdictional Complexity & 0.78 & 1.28 \\
Internal Funding & 0.86 & 1.16 \\
External Funding & 0.87 & 1.15 \\
Organizational Complexity & 0.81 & 1.23 \\
\hline
\end{tabular}

The second assumption is that there is no heteroscedasticity, or there is an equal variance in errors. The Time Honored Method of Inspection (THMI) analyzed the scatter plot of regression-standardized residuals and the dependent variable of technology adoption in order to identify a potential funneling effect. As displayed in Figure 1, there is no evidence of a funneling effect in this model.

The third assumption of OLS regression is that there is no evidence of autocorrelation. A positive autocorrelation results in too small of a error variance which results in an increase of the Type 1 error rate, and a negative autocorrelation results in too large of an estimate, reducing power. A Durbin-Watson statistic is a measure of autocorrelation of errors, and when its value approaches 2.0, independence of the data can be assumed. The Durbin-Watson statistic in this analysis is valued at 1.77; while this value is not as near to the value of 2.0 as desired, it is sufficient for the continuation of the regression analysis. 


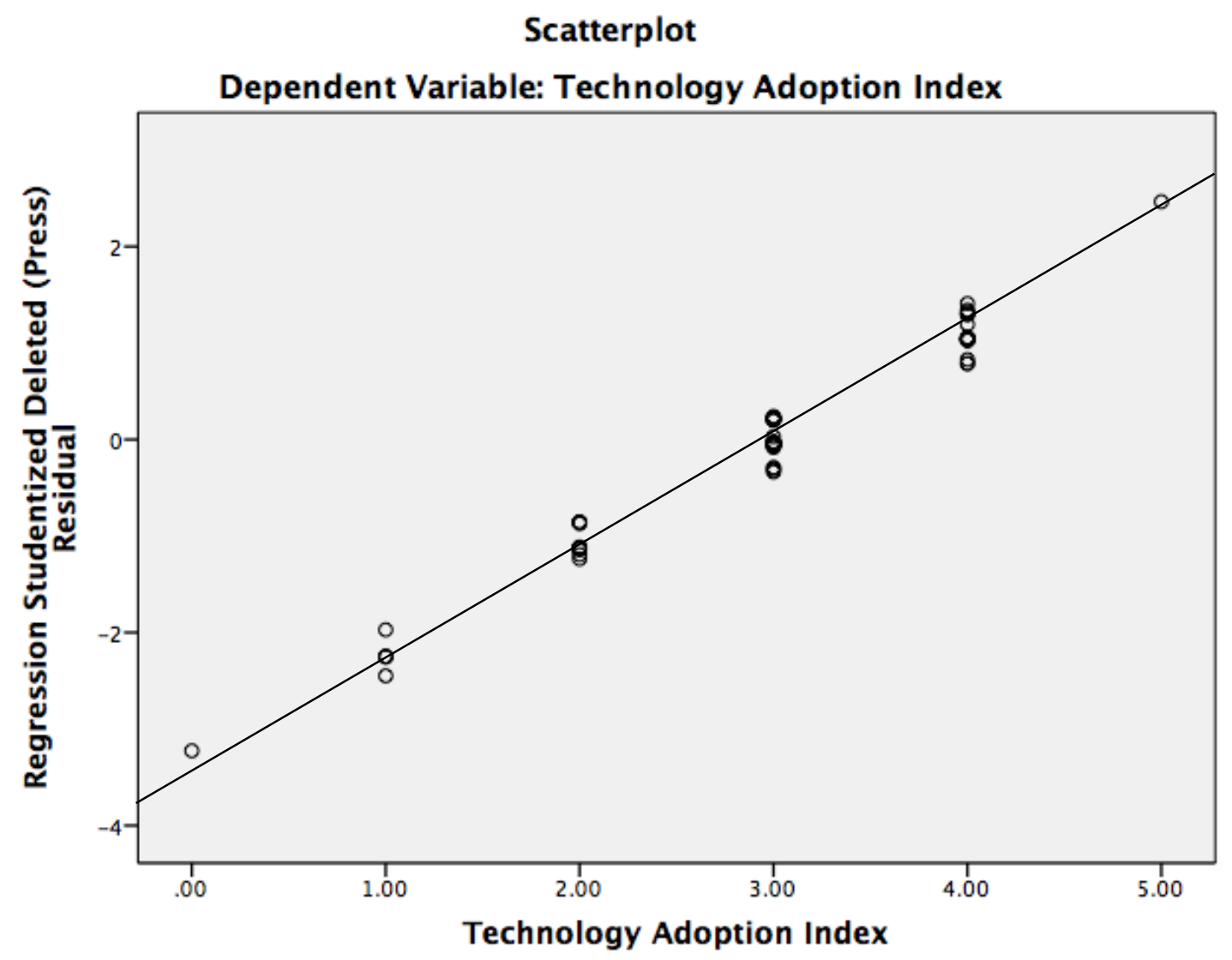

Figure 1. THMI diagnostic

The fourth assumption for OLS regression is that the error terms are normally distributed. Normal distribution can be determined through the analysis of a Normal PPlot. When the plot remains close to the line, it indicates that the error terms are normally distributed. Figure 2 displays the Normal P-Plot for this analysis. As shown, the error terms are not normally distributed, though the cause for the issue is unclear. Cook's D, DFFITS, and DFBETAS values each remained lower than 1, indicating that outliers should not have an effect on the OLS regression analysis. 


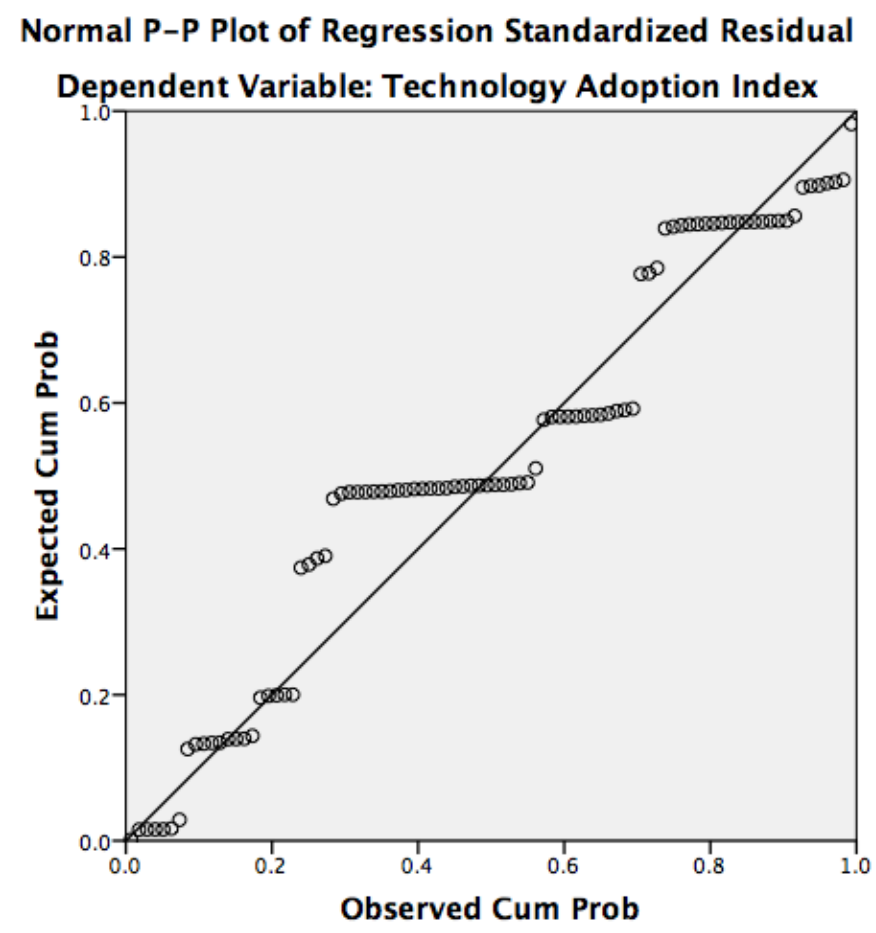

Figure 2. Normal P-P plot

In order to thoroughly address research questions one through three, multivariate analysis was conducted to assess the statistical relationship between jurisdictional complexity, funding (internal and external), and organizational complexity and the adoption of multiple law enforcement technologies (RMS, broadband networking, LRAD, patrol cameras, and BWC). The results of the OLS regression showed no significant association between the technology adoption index variable and any of the independent variables of jurisdictional complexity, internal funding, external funding, and organizational complexity (See Table 21). The lack of statistically significant relationships may be a result of the small sample size $(n=90)$ as well as the lack of normal distribution of error terms. 
Table 21

OLS Regression For Prediction of Technology Adoption

\begin{tabular}{llccr}
\hline Variable & \multicolumn{1}{c}{$b$} & $\mathrm{SE}$ & $\beta$ & $p$ \\
\hline Jurisdictional Complexity & 0.23 & 0.23 & 0.12 & 0.32 \\
Internal Funding & -0.22 & 0.47 & -0.05 & 0.65 \\
External Funding & -0.24 & 0.22 & -0.13 & 0.27 \\
Organizational Complexity & 0.01 & 0.11 & 0.02 & 0.90 \\
Constant & 3.03 & 0.53 & & 0.00 \\
\hline
\end{tabular}

Note. Model $\mathrm{R}^{2}=0.02, \mathrm{n}=90$.

\section{Conclusion}

This chapter combined several univariate, bivariate, and multivariate analyses to answer the proposed research questions of (1) How does the organizational complexity (i.e. number of officers employed, number of bureaus and divisions, and number of ranks) of a law enforcement agency influence the decision to adopt new technologies? (2) How does the jurisdictional complexity (i.e. whether the community is urban, suburban, or rural) of a law enforcement agency influence the decision to adopt new technologies? (3) Does the presence of funding (i.e. internal and external) influence the likelihood that an agency will adopt new technology? (4) What are some common justifications for adopting records management systems, broadband networking with vehicle computers, long range acoustic devices, patrol vehicle cameras, and body-worn cameras?

Question one was addressed through a series of $t$-tests, which indicated that agencies with a higher number of ranks and divisions were more likely to have adopted RMS technology. Higher numbers of divisions also displayed a statistically significant relationship to the adoption of broadband technology. In order to answer question two, a series of chi square analyses were conducted. The only significant relationship was found between jurisdictional complexity and broadband networking technology, indicating that 
rural jurisdictions are less likely to have broadband networking technology than suburban and urban jurisdictions. Question three was also addressed through chi-square analyses. The presence of internal funding was found to have a statistically significant relationship with the adoption of patrol vehicle cameras and BWC. In order to answer question four, frequency statistics of the dependent variable of justifications were utilized. The results indicated that officer safety, efficiency, and community safety appeared to be the most common justifications for technology use, ranking consistently in the top three for every iteration of the analysis.

Bivariate correlations did not indicate any statistically significant relationship between the summative measure of adopted technologies and the organizational complexity factor score, jurisdictional complexity, internal funding, nor external funding. However, the analyses did indicate statistically significant positive relationships between jurisdictional complexity and external funding, jurisdictional complexity and organizational complexity, and internal funding and organizational complexity. It also indicated a negative relationship between internal and external funding. While OLS regression analysis was implemented to comprehensively address research questions one, two, and three, no statistically significant relationships were identified as a result of the analysis. This may be due to the small sample size or the lack of normal distribution of error terms. The following chapter will discuss the results of the current research study in detail, identifying limitations of the research as well as implications of the study, determining a direction for future research. 


\section{CHAPTER VI \\ DISCUSSION}

\section{Introduction}

Prior research in the area of law enforcement technology has primarily been normative in nature, focusing on the effectiveness of specific technologies in addressing specific needs of law enforcement agencies with the goal of prescribing recommendations for improvement. The problem with such research is the lack of acknowledgement that the decision to adopt law enforcement technologies may be independent of the feasibility and effectiveness of the technology. External events and societal pressures are important factors that must be considered when studying the policy decisions of law enforcement agencies. Institutional theorists, Ritti and Mastroski (2002), found that pressures to conform to the desires of institutional sovereigns can lead to the adoption of policy. Law enforcement agencies operate at the discretion of the communities and governments they serve. Resources are ultimately controlled by these sovereigns, so law enforcement agencies are susceptible to the political and social pressures of these sovereigns.

The purpose of this exploratory study was to approach technology research from the institutional theory perspective in order to expand upon previous law enforcement technology research by examining the use of five technologies by county and municipal law enforcement agencies. By acknowledging external influences of sovereigns, the study 
was designed to address an identified gap in previous studies by addressing contextual factors often ignored in technology research.

The previous chapter addressed the quantitative analysis and findings for the four research questions outlined in the research design. The following section will relate these findings to prior literature in the areas of law enforcement technology and institutional theory as applied to law enforcement agencies. Following the discussion of the results, the limitations of this study are identified and recommended directions for future research are addressed.

\section{Discussion}

\section{Organizational Complexity}

Crank and Langworthy (1996) proposed that the political influences from sovereigns resulted in an increase in the number of organizational structures as well the policies and programs utilized by the organization. The results from the current study supported this proposal, specifically concerning the adoption of records management systems and broadband networking technology. The organizational complexity factors of ranks and divisions were positively correlated to the use of records management systems. Higher numbers of divisions were also related to the adoption of broadband networking technology. Strong communications systems are essential to the operation of complex organizations. Records management and broadband are likely utilized more often in these larger structures to ensure officers are able to transmit and track down essential information efficiently. The remaining technologies evaluated do not necessarily improve upon the efficacy of an agencies' operations, which could explain the lack of a significant relationship between those technologies and organizational complexity. 
From an institutional theory perspective, a connection between external funding and organizational complexity would be expected. The logic implies that a complex institutional environment, that is an environment with a large number of sovereigns, would result in a complex organization. The presence of these sovereigns should result in a greater amount of external funding. This study does not support this hypothesis.

However, there does appear to be a connection between internal funding and organizational complexity. While this is not explained by institutional theory, this result is not unexpected. Complex law enforcement agencies are more likely to exist in areas with greater jurisdictional complexity, as identified in the analysis. These agencies have larger tax base, increasing the internal funding available for use.

\section{Jurisdictional Complexity}

Of the five technologies identified, only broadband networking technology had a significant relationship with the variable of jurisdictional complexity. Specifically, the analysis indicated that rural jurisdictions are less likely to have broadband networking technology. Bivariate correlation also indicated a significant relationship between jurisdictional complexity and external funding. These findings are supported by Gordon et al (2012), who identified that $62 \%$ of surveyed small law enforcement agencies acknowledged that communications infrastructure and technology presented difficulties for their agencies. This result is also supported by the institutional theory framework. Less complex agencies do not answer to as many sovereigns. As a result, these agencies may lack the resources offered by institutional sovereigns as rewards for conformity (Scott \& Meyer, 1983). The adoption of broadband networking technology is cost prohibitive for smaller agencies that lack the external resources to help cover 
implementation costs (Gordon et al, 2012; Carter \& Grommon, 2014). Outside of the institutional theory framework, the geographical composition of a rural jurisdiction presents additional challenges to agencies, as the infrastructure needed to ensure broadband networking systems work effectively in a large coverage area would be complex. It also may require cooperation from land owners so components could be placed strategically in the coverage area.

The statistical strength of the sample may explain the lack of relationships indicated during regression analysis. Logically, the most complex organizations would operate in large urban agencies. The sample of this study contained a majority of rural agencies (63.2\%), with only 8 agencies identifying their jurisdictions as urban. The overrepresentation of non-complex agencies may have resulted in the lack of findings between institutional factors and technology adoption.

\section{Funding}

The complexity of an agency and its jurisdiction appears to be a factor in the decision to adopt various law enforcement technologies. From the institutional theory perspective, funding can be derived from sovereigns as a reward for compliance and conformity to policies desired by the sovereign (Engel, Calnon, \& Bernard, 2001). The presence and use of external funding implies the presence and influence of sovereigns; therefore, testing of the influence of external funding on the decision to adopt technology was a goal of this study. The analysis did not indicate any direct relationship between the use of external funding and a technology. However, the analysis of internal funding indicated that agencies with patrol vehicle cameras were more likely to use internal funding, and those with body-worn cameras would be less likely to utilize internal 
funding. While this difference may have resulted due to the small number of agencies who identified their use of BWCs $(n=35)$ as compared to patrol vehicle cameras $(n=83)$, there may be an additional explanation.

Controversy in law enforcement practices and concerns for officer and community safety have largely been responsible for the push to increase the use of these technologies. Initiatives to increase the affordability of these technologies were developed and implemented as a result. The In-Car Camera Initiative Program was introduced in 2000, and the Body-worn Camera Partnership Program was announced in 2014 (International Association of Chiefs of Police, 2004; Nash \& Scarberry, 2014; The White House Office of the Press Secretary, 2014). The In-Car Camera Initiative Program appeared to be successful in increasing the use of patrol vehicle cameras between 2000 and 2007 (IACP, 2004; Reaves, 2010). However, now that it is assumed that all patrol vehicles are equipped with cameras, external pressure and offers for funding may no longer be available (Westphal, 2004; IACP, 2004; Reaves, 2010). Internal funding must be used as the primary resource for upkeep and replacements. Body-worn cameras, being a largely new form of technology, have not been implemented at the rate of patrol vehicle cameras. Agencies with BWCs are less dependent on internal funding to cover the costs of this technology due to the incentive programs available for their use. As initiative programs, such as the Body-worn Camera Partnership Program, become available, law enforcement agencies are likely to increase the number of BWCs used nationally. 


\section{Justifications for Technology Adoption}

In this study, the justifications for the use of technology could be categorized as acceptance of organizational myths. These "understandings of social reality" (Crank, 2003, p. 189) support the choices made by the agency, protecting the organization from criticism because the myths reflect values held by their sovereigns (Crank, 2003; Crank \& Langworthy, 1992). Officer safety, efficiency, and community safety, the most common responses from responding agencies, can be categorized as myths due to the lack of consistent empirical evidence that these technologies actually perform these duties. For example, broadband networking with mobile computer terminals may serve as a distraction to officers on the road, presenting a safety threat to themselves and others (Darst, 2014). The lack of interoperability between various agencies' records management systems reduces the efficiency of the technology, and leads to a breakdown in communication between agencies (Skogan, Harnett, \& DuBois, 2003). Some myths may be supported by normative research, which does raise the argument that agencies are not internalizing falsehoods. However, one must consider the motivations for accepting these "truths." Accepting these myths and presenting them to sovereigns may be beneficial when approaching sovereign entities for financial assistance, as these groups may be more amiable when presented with requests that support causes they value (IACP, 2006).

\section{Other Findings}

Ultimately, this study found very little support indicating a relationship between institutional factors and the decision to adopt technologies overall. However, findings from the bivariate correlation analyses indicated statistically significant positive 
relationships between the institutional factors of jurisdictional complexity and external funding, jurisdictional complexity and organizational complexity, and internal funding an organizational complexity. From an institutional theory perspective, this would be expected. As Crank (2003) indicated, the complexity of the institutional environment is directly reflected by the organization, which becomes more complex itself to handle the demands of the institutional environment and the demands of sovereigns in that environment. As the complexity of a jurisdiction increases, the amount of funding available from external funding sources should increase due to the larger number of potential funding sources. Similarly, more complex organizations should have larger budgets, so internal funding would be correlated.

\section{Limitations}

As with any research study, there were limitations in the implementation of the current study. Several limitations resulted from the survey and initial sample group. As identified before, only 106 agencies completed the survey of the original 902 approached, constituting a $12 \%$ response rate. This may have been due to the short submission window. The digital version of the survey went live on November $16^{\text {th }}$, and was closed in early January. The physical versions were mailed to agencies in mid-December, and new submissions were not accepted for analysis after January $15^{\text {th }}$. The time constraints were necessary to ensure data analysis could be completed in a timely manner; however, the short submission windows could prove to have been detrimental to the response rate.

As a result of the poor response rate, the generalizability of any analysis is highly questionable, especially as the agencies who did respond primarily served rural jurisdictions (63.2\%) with a small fraction serving urban jurisdictions (7.5\%). 
Admittedly, the jurisdictional breakdown for the national population is not that different. Urban jurisdictions represent only $6.2 \%$ of the country, though these areas contain $58.5 \%$ of the national population (FBI, 2012). While it does appear that the respondents could constitute a representative sample, the over representation of rural agencies did not allow for a statistically sound comparison between jurisdiction type.

Another issue involving the application of surveys was the need to distribute both digital and physical versions. Many of the agencies selected for the study did not have email contact information readily available on agency websites or social media. As a result, the survey format had to be altered to work in a physical format, and 380 surveys were sent through the U.S. Postal Service. This reduced the clarity of some of the questions, as was evident from the surveys submitted for analysis. This format was somewhat beneficial, as none of the submissions were incomplete. Ten respondents completed a majority of the survey; however, as the technology survey was included in the second half, the sections that remained unfinished left any data collected unusable. Another factor that may have affected the return rate, as well as the validity of the data submitted, were events that occurred at the time of survey distribution. As stated before, the survey was conducted in parts in order to study two phenomenon: terrorism preparedness and law enforcement technology. Each of these topics can be controversial on their own. Unfortunately, the timeline for survey distribution fell in line with both the terrorist attacks in Paris and San Bernardino. As a result, agencies may have been reluctant to respond to any questions about the capabilities of their departments, reducing the number of willing participants in these studies. 


\section{Recommendations for Future Research}

As stated before, institutional theorists posit that the complexity of the institutional environment is ultimately reflected in the organization, becoming complex in structure as a result (Crank, 2003). The current study intentionally ignored agency size during the selection process, hoping to sample a diverse range of agencies. As a result, only eight agencies identified their jurisdictions to be urban. Researchers may benefit from expanding to other states with an effort in targeting larger organizations. Potentially, institutional factors may only have a significant effect on the more complex organizations present in urban jurisdictions. Additional research could compare the influences institutional factors have between the two groups.

Katz (2001) was successful in applying institutional theory perspectives in an empirical research study. Katz was exploring the decision to develop a gang unit; however, several research design choices could be applied to technology research. First, Katz incorporated qualitative interviews. Second, the research was focused on a single subject. Future studies on technology could improve the quality of the data surrounding the decision to adopt technologies by supplementing the quantitative analysis with qualitative semi-structured interviews. Altering the methodological approach to incorporate in-person interviews could decrease the amount of ambiguity found in the original survey. Future studies could also benefit from focusing on a single technology, such as body-worn cameras or broadband networking. The quantitative analysis from the current study supports such a change in research design. The evaluation of technology adoption as a whole indicated no relationship to any of the institutional theory variables. However, when evaluated on an individual basis, bivariate analysis indicated significant 
relationships between specific technologies and institutional factors. It is likely that the decision to adopt some technologies are subject to stronger external influences than others. Focusing research on the technologies most susceptible to sovereign influences may be more successful than the current research design.

\section{Conclusion}

While the majority of the tested variables displayed little to no relationship to the decision to adopt records management systems, broadband networking with vehicle computers, long range acoustic devices, patrol vehicle cameras, and body-worn cameras, a few conclusions can be made from the data provided. First, complex organizations appear to have a greater dependence on communications technologies. These agencies rely on IT infrastructures that allow for clear and efficient transfer of information. Organizations that operate in less complex jurisdictions are less likely to utilize broadband networking. This is partially due to the decreased need for the technology, while the cost prohibitive nature of installing such a system in a rural environment also plays a factor.

The second conclusion that can be made is the role controversy and politics make in the availability of funding. While this was not addressed directly in this study, the increased implementation of patrol vehicle cameras in the early 2000s may have directly resulted from allegations of police misconduct (IACP, 2004; Nash \& Scarberry, 2014). Similarly, the call to implement the use body-worn cameras is a direct result of accusations of police misconduct in high profile police shootings. As a result of these political pressures, initiatives designed to help fund the implementation of these technologies were introduced (IACP, 2004; Nash \& Scarberry, 2014; The White House 
Office of the Press Secretary, 2014). The results from this study indicate that the sources of funding will likely shift from external to internal as the technology ages and its use becomes commonplace.

The final conclusion is that agencies will often justify their use of technology through the acceptance of organizational myths. The myths of officer safety, efficiency, and community safety are not necessarily supported by research, but they are believed to be correct. These myths help justify the decision to adopt technologies as legitimate because it is for "the greater good." These myths also become selling points for agencies when attempting to gain external funding. In the case of patrol vehicle cameras, Chief Montie Sims of the Dardanelle, Arkansas Police Department stated, "While the fact of the conveniences of having the in-car cameras sometimes are a hard selling point, a chief using the argument of officer safety is often successful" (IACP, 2006).

The statistical strength of this research is not particularly strong, especially considering the low return rate and underrepresentation of agencies who serve urban jurisdictions. Additional targeted research will be necessary in order to make any generalizable conclusions about the role of institutional factors have over the decision to adopt law enforcement technologies. However, this exploratory analysis does provide a foundation for future research development. While additional research will be necessary to determine the strength of external influences on organizational decision-making, it would not be remiss for agency administrators to remain cognizant of these potential influences. It is not in the best favor of an agency, or its community, to invest in technology for the sake of politics alone. Like all policies, evidence-based practice should be shown preference. Evaluation of normative research studies focused on individual 
technologies is one method that could be utilized by agency administrators to ensure that investment in a particular technology is the right choice for an agency. 


\section{REFERENCES}

Agrawal, M., Rao, H.R., \& Sanders, G.L. (2003). Impact of mobile computing terminals in police work. Journal of Organizational Computing and Electronic Commerce, 13(2), 73-89.

Ariel, B., Farrar, W.A., \& Sutherland, A. (2015). The effect of police body-worn cameras on the use of force and citizens' complaints against the police: A randomized controlled trial. Journal of Quantitative Criminology, 31(1), 509-535.

Becker, A., \& Schulz, G.W. (2011). Local police stockpile high-tech, combat-ready gear. Retrieved from http://cironline.org/reports/local-police-stockpile-high-techcombat-ready-gear-2913

Bernard, T., \& Engel, R. (2001). Conceptualizing criminal justice theory. Justice Quarterly, 18, 1-30.

Carter, J.G. \& Grommon, E. (2014). Wireless broadband for municipal police: Evaluating clearance times of calls for service. Police Quarterly, 17(3), 226-249.

Chappell, A.T., MacDonald, J.M, \& Manz, P.W. (2006). The organizational determinants of police arrest decisions. Crime \& Delinquency, 52(2), 287-306.

Combs, B. (2014). Curb complaints with little cameras. Kentucky Law Enforcement Magazine, 13(1), 24-25.

Considering police body cameras (Vol. 128). (2015). Cambridge, MA: Harvard Law Review Association.

Crank, J.P. (2003). Institutional theory of police: A review of the state of the art. Policing: An International Journal of Police Strategies \& Management, 26(2), $186-207$.

Crank, J.P. (1994). Watchman and community: myth and institutionalization in policing. Law and Society Review, 28, 325-51.

Crank, J.P. (1990). The influence of environmental and organizational factors on police style in urban and rural environments. Journal of Research in Crime and Delinquency, 27(2), 166-189. 
Crank, J.P., \& Langworthy, R. (1996), Fragmented centralization and the organization of the police. Policing and Society, 6, 213-29.

Crank, J.P., \& Langworthy, R. (1992). An institutional perspective of policing. Journal of Criminal Law and Criminology, 83, 338-63.

Darst, A. (2014). Cruiser technology- The convenience, the curse. Kentucky Law Enforcement Magazine, 62-67.

Dunham, R.G., \& Alpert, G.P. (2015). Critical issues in policing: Contemporary readings $\left(7^{\text {th }}\right.$ ed.). Long Grove, IL: Waveland Press.

Engel, R., Calnon, J. and Bernard, T. (2002). Theory and racial profiling: shortcomings and future directions in research. Justice Quarterly, 19(2), 249-75.

Falcone, D.N., Wells, L.E., \& Weisheit, R.A. (2002). The small-town police department. Policing: An International Journal of Police Strategies \& Management, 25(2), 371-384.

Federal Bureau of Investigation, Criminal Justice Information Services Division. (n.d.). Law enforcement records management systems (RMSs) as they pertain to FBI programs and systems [Report]. Retrieved from https://www.fbi.gov/aboutus/cjis/law-enforcement-records-management-system/

Garicano, L., \& Heaton, P. (2010). Information technology, organization, and productivity in the public sector: Evidence from police departments. Journal of Labor Economics, 28(1), 167-201.

Graham v. Connor, 490 U.S. 386 (1989).

Gordon, J., Wallace, B.A., Tremblay, D., \& Hollywood, J. (2012). Keeping law enforcement connected: Information technology needs from state and local agencies. National Institute of Justice.

Guarino, M. (2014, November 26). Video of Tamir Rice shooting shows moment police kill 'peace-loving' boy. The Guardian. Retrieved from http://www.theguardian.com/us-news/2014/nov/26/video-tamir-rice-shootingpolice-peace-loving-boy

Hollywood, J.S., Boon, J.E., Silberglitt, R., Chow, B.G., \& Jackson, B.A. (2015). Highpriority information technology needs for law enforcement. National Institute of Justice. 
International Association of Chiefs of Police (2004). The impact of video evidence on modern policing: Research and best practices from the IACP study on in-car cameras. Alexandria, VA: International Association of Chiefs of Police.

International Association of Chiefs of Police (2005). Law enforcement priorities for public safety: Identifying critical technology needs. Alexandria, VA: International Association of Chiefs of Police.

International Association of Chiefs of Police (2006). Technology technical assistance program: In-car cameras. Alexandria, VA: International Association of Chiefs of Police.

International Association of Crime Analysts Standards, Methods, and Technology Committee. (2013). RMS technical requirements for crime analysis, Overland Park, KS: n.a.

Ioimo, R.E., \& Aronson, J.E. (2004). Police field mobile computing: Applying the theory of task-technology fit. Police Quarterly, 7(4), 403-428.

Jennings, W.G., Lynch, M.D., \& Fridell, L.A. (2015). Evaluating the impact of police officer body-worn cameras (BWCs) on response-to-resistance and serious external complaints: Evidence from the Orlando police department (OPD) experience utilizing a randomized controlled experiment. Journal of Criminal Justice, 43(6), 480-486.

Katz, C. (2001), The establishment of a police gang unit: an examination of organizational and environmental factors. Criminology, 39(1), pp. 37-74.

Klinger, D.A. (1995). The micro-structure of nonlethal force: Baseline data from an observational study. Criminal Justice Review, 20(2), 169-186.

Koper, C.S., Lum, C., Willis, J.J. (2014). Realizing the potential of technology for policing. Translational Criminology, 7, 9-17.

Koper, C.S., Taylor, B.G., \& Kubu, B.E. (2009). Law enforcement technology needs assessment: Future technologies to address the operational needs of law enforcement. Washington, D.C.: Police Executive Research Forum and Lockheed Martin Corporation.

Koper, C., Taylor, B., \& Woods, D. (2013). A randomized test of initial and residual deterrence from directed patrols and use of license plate readers at crime hot spots. Journal of Experimental Criminology, 9(2), 213-244.

Langworthy, R. (1986). The structure of police organizations. New York, NY: Praeger. 
Laughland, O., Glenza, J, \& Thrasher, S. (2014, December 4). 'We can't breathe': Eric Garner's last words become protesters' rallying cry. The Guardian. Retrieved from http://www.theguardian.com/us-news/2014/dec/04/we-cant-breathe-eric-garnerprotesters-chant-last-words

Law Enforcement Information Technology Standards Council. (2010). Standard functional specifications for law enforcement records management systems version 2. Washington, D.C.: Office of Justice Programs.

LRAD Corporation. (2014). Law enforcement solutions: Saving lives through clear communication. San Diego, CA: n.a.

LRAD Corporation. (2014). Product guide LRAD systems and accessories: Enhancing safety through long range communication. San Diego, CA: n.a.

Mastrofski, S., \& Uchida, C. (1996). Transforming the police. In Hancock, B. and Sharp, P. (Eds.), Public policy: Crime and criminal justice (pp. 196-219). Upper Saddle River, NJ: Prentice-Hall.

Meyer, J., \& Rowan, B. (1977). Institutionalized organizations: formal structure as myth and ceremony. American Journal of Sociology, 83(2), pp. 340-63.

Meyer, J., Scott, W.R., \& Deal, T. (1983). Institutional and technical sources of organizational structure: Explaining the structure of educational organizations. In Meyer, J. and Scott, W. (Eds.), Organizational environments: Ritual and rationality (updated ed.) (pp. 45-70). New York, NY: Sage Publications.

Nash, A.C., \& Scarberry, J.L. (2014). Let's have a look at the footage. Law Enforcement Technology, 41(3), 45-47.

National Institutes of Health. (2014). Noise-induced hearing loss (NIH Publication No. 14-4233). Washington, DC: U.S. Government Printing Office.

National Institute of Justice. (2014). Body-worn cameras for criminal justice: Market survey. Washington, DC: U.S. Government Printing Office.

National Institute of Justice. (2012). A primer on body-worn cameras for law enforcement. Washington, DC: U.S. Government Printing Office.

National Institute of Justice. (2010). High-priority criminal justice technology needs. Washington, DC: U.S. Government Printing Office. 
Northrop Grumman. (2006). Northrop Grumman wins \$500 million New York City broadband mobile wireless contract [Press Release]. Retrieved from http://www.globenewswire.com/newsarchive/noc/press/pages/news_releases.html $? \mathrm{~d}=105089$

Pearsall, B. (2010). Predictive policing: The future of law enforcement. National Institute of Justice Journal, 266, 16-19.

Reaves, B.A. (2010). Local police departments, 2007. Bureau of Justice Statistics.

Ritti, R.R. and Mastrofski, S. (2002). The institutionalization of community policing (Unpublished manuscript).

Sanders, C.B., \& Henderson, S. (2013). Police 'empires' and information technologies: Uncovering material and organizational barriers to information sharing in Canadian police services. Policing \& Society, 23(2), 243-260.

Schrantz, B.D. (2010). The long range acoustic device: Don't call it a weapon- Them's fightin' words. The Army Lawyer, 53-59.

Schwabe, W., Davis, L.M., \& Jackson, B.A. (2001). Challenges and choices for crimefighting technology: Federal support of state and local law enforcement. Santa Monica, Calif.: RAND Corporation.

Scott, R., \& Meyer, J. (1983). The organization of societal sectors. In Meyer, J. and Scott, R. (Eds.), Organizational environments: Ritual and rationality (pp. 129155). Newbury Park, CA: Sage Publications.

Scott, W. (2005). Institutional theory. In G. Ritzer (Ed.), Encyclopedia of social theory (pp. 409-415). Thousand Oaks, CA: Sage Publications. doi: http://dx.doi.org/10.4135/9781412952552.n155

Skogan, W., Harnett, S. M., \& DuBois, J. (2003). Policing smarter through IT: Learning from Chicago's Citizen \& Law Enforcement Analysis \& Reporting System.

Speed, A.K. (2015, December 4). In aftermath of San Bernardino shooting, training is key, police say. Daily Press. Retrieved from http://www.dailypress.com/news/crime/dp-nws-shooting-folo-20151204story.html

Swaine, J., \& Laughland, O. (2015, March 4). Darren Wilson will not face federal charges in Michael Brown shooting. The Guardian. Retrieved from http://www.theguardian.com/us-news/2015/mar/04/darren-wilson-federalcriminal-charges-michael-brown-shooting 
Swaine, J., \& Laughland, O. (2015, May 1). Freddie Gray died after head 'slammed into bolt in police van', reports say. The Guardian. Retrieved from

http://www.theguardian.com/us-news/2015/apr/30/baltimore-police-van-freddiegray-stop

United States Department of Justice, Federal Bureau of Investigation. (September 2012). Crime in the United States, 2011. Retrieved from https://www.fbi.gov/aboutus/cjis/ucr/crime-in-the-u.s/2011/crime-in-the-u.s.-2011/tables/table_77_fulltime_law_enforcement_employees_by_state_2011.xls

Vicinanzo, A. (2015, June 1). Baltimore, Ferguson spark debate over body-worn cameras for law enforcement. Homeland Security Today. Retrieved from http://www.hstoday.us/briefings/daily-news-analysis/single-article/baltimoreferguson-spark-debate-over-body-worn-cameras-for-lawenforcement/139c860eb5ee015108ddef9fe91d7b91.html

Weisheit, R.A., Wells, L.E., \& Falcone, D.N. (1994). Community policing in small town and rural America. Crime \& Delinquency, 40(4), 549-567.

Westphal, L.J. (2004). The in-car camera: Value and impact. The Police Chief, 71(8) n.p. Retrieved from

http://www.policechiefmagazine.org/magazine/index.cfm?fuseaction=display\&art icle_id $=358$

The White House. (2011). The benefits of transitioning to a nationwide wireless broadband network for public safety [Report]. Washington, DC: U.S. Government Printing Office.

The White House, Office of the Press Secretary. (2014). Fact sheet: Strengthening community policing [Press release]. Retrieved from https://www.whitehouse.gov/the-press-office/2014/12/01/fact-sheetstrengthening-community-policing

Wexler, C. (2012). How are innovations in technology transforming policing? Washington, DC: Police Executive Research Forum.

Wood, M. (Producer). (2012, April 20). LRAD- Long range acoustic hailing devices [Episode 3]. Digital Justice. Retrieved from http://on.aol.com/partner/digitaljustice-517198427

Woolf, N. \& Gosztola, K. (2015, December 1). Chicago police chief fired after Laquan McDonald shooting revelations. The Guardian. Retrieved from http://www.theguardian.com/us-news/2015/dec/01/chicago-mayor-fires-policesuperintendent-laquan-mcdonald-shooting-protests 


\author{
APPENDIX A \\ SURVEY DISTRIBUTED TO AGENCIES
}

Technology Survey

1. Does your agency have a COMPUTER-BASED RECORDS MANAGEMENT SYSTEM?

1 YES

$2 \mathrm{NO}$

IF YES, is the computer-based records management system used to: (check all that apply)

1 INCREASED OFFICER SAFETY

2 INCREASE COMMUNITY SAFETY

3 INCREASE EFFICIENCY

4 MEET FEDERAL LEGAL REQUIREMENTS

5 MEET STATE LEGAL REQUIREMENTS

6 MEET WRITTEN POLICY REQUIREMENTS

7 ADDRESS A CRIME PROBLEM

IF YES, how often is this technology actually used by your agency?

1 EVERYDAY

2 MONTHLY

3 EVERY SIX MONTHS

4 EVERY YEAR

5 ONCE

6 NEVER

IF YES, what criticisms does your agency have regarding this technology? What improvements are needed?

IF NO, does your agency have plans to obtain a computer-based records management system in the future?

1 WE HAVE NO DESIRE TO USE THIS TECHNOLOGY

2 WE WANT IT, BUT HAVE NO IMMEDIATE PLANS TO OBTAIN IT

3 WE ARE IN THE PLANNING STAGES OF ACQUIRING THIS TECHNOLOGY 
2. Does your agency have BROADBAND NETWORKING WITH VEHICLE COMPUTER SYSTEMS?

$$
\begin{aligned}
& 1 \text { YES } \\
& 2 \mathrm{NO}
\end{aligned}
$$

IF YES, are the broadband networking with computer systems used to: (check all that apply)

$$
\begin{aligned}
& 1 \text { INCREASED OFFICER SAFETY } \\
& 2 \text { INCREASE COMMUNITY SAFETY } \\
& 3 \text { INCREASE EFFICIENCY } \\
& 4 \text { MEET FEDERAL LEGAL REQUIREMENTS } \\
& 5 \text { MEET STATE LEGAL REQUIREMENTS } \\
& 6 \text { MEET WRITTEN POLICY REQUIREMENTS } \\
& 7 \text { ADDRESS A CRIME PROBLEM }
\end{aligned}
$$

IF YES, how often is this technology actually used by your agency?

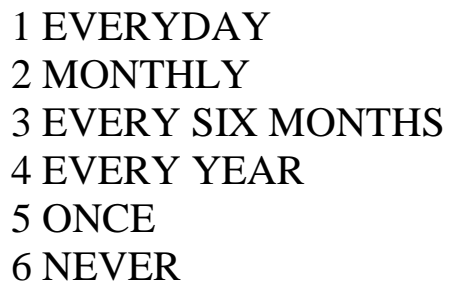

IF YES, what criticisms does your agency have regarding this technology? What improvements are needed?

IF NO, does your agency have plans to obtain broadband networking in the future?

1 WE HAVE NO DESIRE TO USE THIS TECHNOLOGY

2 WE WANT IT, BUT HAVE NO IMMEDIATE PLANS TO OBTAIN IT

3 WE ARE IN THE PLANNING STAGES OF ACQUIRING THIS TECHNOLOGY

3. Does your agency have LONG-RANGE ACOUSTIC DEVICES (LRAD)?

$$
\begin{aligned}
& 1 \text { YES } \\
& 2 \mathrm{NO}
\end{aligned}
$$

IF YES, is the LRAD used to: (check all that apply)

1 INCREASED OFFICER SAFETY

2 INCREASE COMMUNITY SAFETY

3 INCREASE EFFICIENCY

4 MEET FEDERAL LEGAL REQUIREMENTS

5 MEET STATE LEGAL REQUIREMENTS

6 MEET WRITTEN POLICY REQUIREMENTS 


\section{ADDRESS A CRIME PROBLEM}

IF YES, does your agency have written policies outlining how it is used?

1 YES

$2 \mathrm{NO}$

IF YES, how often are officers required to complete training on the equipment?

1 NOT AT ALL

2 ONCE

3 ANNUALLY

4 MORE THAN ANNUALLY

5 MORE THAN ONCE, LESS THAN ANNUALLY

IF YES, when was the last time training was offered to line officers outside of the academy/FTO?

1 WITHIN THE LAST 6 MONTHS

2 WITHIN THE LAST YEAR

3 LONGER THAN A YEAR AGO

IF YES, how often is this technology actually used by your agency?
1 EVERYDAY
2 MONTHLY
3 EVERY SIX MONTHS
4 EVERY YEAR
5 ONCE
6 NEVER

IF YES, what criticisms does your agency have regarding this technology? What improvements are needed?

IF NO, does your agency have plans to obtain LRAD in the future?

1 WE HAVE NO DESIRE TO USE THIS TECHNOLOGY

2 WE WANT IT, BUT HAVE NO IMMEDIATE PLANS TO OBTAIN IT

3 WE ARE IN THE PLANNING STAGES OF ACQUIRING THIS TECHNOLOGY

4. Does your agency have PATROL VEHICLE CAMERAS?

$1 Y E S$

$2 \mathrm{NO}$

IF YES, are patrol vehicles used to: (check all that apply)

1 INCREASED OFFICER SAFETY

2 INCREASE COMMUNITY SAFETY

3 INCREASE EFFICIENCY

4 MEET FEDERAL LEGAL REQUIREMENTS 
5 MEET STATE LEGAL REQUIREMENTS

6 MEET WRITTEN POLICY REQUIREMENTS

7 ADDRESS A CRIME PROBLEM

IF YES, does your agency have written policies outlining how it is used?

1 YES

$2 \mathrm{NO}$

IF YES, how often are officers required to complete training on the equipment?

1 NOT AT ALL

2 ONCE

3 ANNUALLY

4 MORE THAN ANNUALLY

5 MORE THAN ONCE, LESS THAN ANNUALLY

IF YES, what criticisms does your agency have regarding this technology? What improvements are needed? future?

IF NO, does your agency have plans to obtain patrol vehicle cameras in the

1 WE HAVE NO DESIRE TO USE THIS TECHNOLOGY

2 WE WANT IT, BUT HAVE NO IMMEDIATE PLANS TO OBTAIN IT

3 WE ARE IN THE PLANNING STAGES OF ACQUIRING THIS TECHNOLOGY

5. Does your agency have BODY-WORN CAMERAS?

1 YES

$2 \mathrm{NO}$

IF YES, are the body-worn cameras used to: (check all that apply)

1 INCREASED OFFICER SAFETY

2 INCREASE COMMUNITY SAFETY

3 INCREASE EFFICIENCY

4 MEET FEDERAL LEGAL REQUIREMENTS

5 MEET STATE LEGAL REQUIREMENTS

6 MEET WRITTEN POLICY REQUIREMENTS

7 ADDRESS A CRIME PROBLEM

IF YES, does your agency have written policies outlining how it is used?

1 YES

$2 \mathrm{NO}$

IF YES, how often are officers required to complete training on the equipment? 
1 NOT AT ALL

2 ONCE

3 ANNUALLY

4 MORE THAN ANNUALLY

5 MORE THAN ONCE, LESS THAN ANNUALLY

IF YES, when was the last time training was offered to line officers outside of the academy/FTO?

1 WITHIN THE LAST 6 MONTHS

2 WITHIN THE LAST YEAR

3 LONGER THAN A YEAR AGO

IF YES, how often is this technology actually used by your agency?

1 EVERYDAY

2 MONTHLY

3 EVERY SIX MONTHS

4 EVERY YEAR

5 ONCE

6 NEVER

IF YES, what criticisms does your agency have regarding this technology? What improvements are needed?

IF NO, does your agency have plans to obtain body-worn cameras in the future?

1 WE HAVE NO DESIRE TO USE THIS TECHNOLOGY

2 WE WANT IT, BUT HAVE NO IMMEDIATE PLANS TO OBTAIN IT

3 WE ARE IN THE PLANNING STAGES OF ACQUIRING THIS TECHNOLOGY

6. Pertaining to equipment funding, how is your agency paying for your technologies? (check all that apply)

1 INTERNAL FUNDING

2 GRANTS

3 PRIVATE FUNDING

4 OTHER, PLEASE EXPLAIN:

7. Aside from those technologies already listed, are there any technologies or equipment your agency is planning on adopting in the future? If so, please describe the technologies, as well as the rationale for adopting them, and how they will be funded. 


\section{Your Agency}

8. How many sworn/nonsworn officers does your agency employ?

FULL TIME

Sworn Officers:

PART TIME

FULL TIME

Nonsworn Officers:

PART TIME

9. How many rank levels (line officer, sergeant. lieutenant, etc.) does your agency have?

10. How many divisions/bureaus does your agency have?

11. Roughly, how many citizens does your agency serve?

12. Would you describe your jurisdiction as primarily:

1 RURAL

2 SUBURBAN

3 URBAN

4 OTHER, PLEASE EXPLAIN:

13. Does your agency have a WRITTEN counterterrorism policy/plan?

$$
\begin{aligned}
& 1 \text { YES } \\
& 2 \mathrm{NO}
\end{aligned}
$$

14. Does your agency have formal policies on the following: (please circle your answer)

$\begin{array}{lll}\text { USE OF FORCE } & \text { YES } & \text { NO } \\ \text { RACIAL PROFILING } & \text { YES } & \text { NO } \\ \text { CITIZENS COMPLIANCE } & \text { YES } & \text { NO } \\ \text { HOSTAGE SITUATIONS } & \text { YES } & \text { NO }\end{array}$

15. Would you like a summary of the results? If so, please provide either a mailing address or email address. 